\title{
A CONCEPTUAL History OF RECOGNITION IN BRITISH INTERNATIONAL LEGAL THOUGHT
}

\author{
By MARTIN CLARK*
}

\begin{abstract}
This article examines the development of the concept of recognition in the writings of British jurists. It first outlines methodologies of conceptual history as applied to international legal concepts, before examining four strands of development of the concept of recognition from the mid-nineteenth to mid-twentieth centuries. It shows how the concept of recognition moved from examining intra-European diplomatic disagreements, to a focus on Christianity, civilisation and progress that barred nonEuropean communities, to a late colonial-era emphasis on technicalities of government and territory, and eventually a state-centric account that normalised inferiority into difference, before emerging in the interwar period as a 'basic concept' of international law: intensely debated and closely tied to a range of political projects. The article concludes with reflections on why British thinking turns away from recognition in the $1950 \mathrm{~s}$, as the decolonising world turns to a new international law and selfdetermination.
\end{abstract}

Keywords: conceptual history, recognition, British international law, colonialism, imperialism

\section{INTRODUCTION}

\section{A. Recognition and its contexts}

* PhD Candidate and Judge Dame Rosalyn Higgins Scholar, London School of Economics and Political Science; Research Fellow, Melbourne Law School. My deep thanks to my MPhil supervisors Anne Orford and Kirsty Gover, to Gerry Simpson and Chantal Morton for comments, to my examiners Antony Anghie and Janne Nijman, and to the anonymous reviewers and Megan Donaldson for comments on earlier versions of this article. This article is based on an MPhil thesis completed at Melbourne Law School in December 2015, which was generously supported by an Australian Research Council Australian Postgraduate Award. Part VI includes some ideas, arguments and material that appeared, albeit in an earlier and different form, in M Clark, 'British Contributions to the Concept of Recognition during the Interwar Period: Williams, Baty and Lauterpacht', in R McCorquodale and J-P Gauci (eds), British Influences on International Law 1915-2015 (Brill 2016) 110. Terms such as 'natives', 'savages', 'uncivilised', 'barbaric', and so on, are used here extensively, often without quotation marks, due to their frequent use in the materials examined. That use should not be taken as endorsement, but rather as reflecting the language used at time. Statesmen and jurists used these terms to justify and advance projects that committed immense violence and injustice to peoples throughout the world. They are far from quaint and awkward anachronisms. This is perhaps an obvious point, particularly given the arguments I make here. But noting it is imperative because they are still invoked today sometimes in newer, coded forms - but always in similar contexts and for similar purposes, sometimes without any sense of this history and at other times consciously appealing to it. All translations are my own unless otherwise indicated. All errors and omissions remain my own. Email: m.clark1@1se.ac.uk 
In contemporary international law doctrine and teaching, recognition is explained by series of syllogisms, a doctrinal debate, and a set of now familiar case studies and examples. ${ }^{1}$ In its syllogistic form, recognition is the act whereby State A announces its official position about rights, obligations, status or capacity in general under international law, most commonly in relation to a state or government. In the case of recognition of states, State A recognises State B where State A announces that it officially recognises State B's existence as a state. The practical effects of recognition are numerous: that State A will deal with legitimate representatives of State B to the exclusion of other claimants to that mantle; that cases decided by State B's courts will be recognised as legitimate foreign judicial determinations in State A's courts; and so on. As a question of theory, the central dilemma of recognition is its relationship with law: 'Is recognition a question of law or diplomatic policy? What law, if any, governs the decision to grant or withhold recognition?' It is often suggested that the 'declaratory' and 'constitutive' schools of thought offer competing answers to these questions. ${ }^{2}$ For the declarativist, State A's recognition of State B is a declaration that confirms State B's existence. It is State B's fulfilment of the criteria of statehood (whatever they might be) which makes it a state, not an official pronouncement by other members of the international community. This is the dominant theoretical understanding today. ${ }^{3}$ For the constitutivist, the recognition of State B - by both State A and other current members of the international community - is necessary for its legal existence as a state. Recognition does not just declare existing facts. It is the action which constitutes and creates State B's statehood and membership of the international community. Finally, recognition's illustrations are found in the statements of governments, the establishment of embassies, the signing of treaties, decisions of domestic and international courts and tribunals on questions of recognition, and declarations of the UN General Assembly on a polity's membership status. 'Exceptional', 'anomalous' or 'special' cases of statelets, quasi-sovereigns and semi-dependent entities are raised to challenge and complicate these otherwise seemingly straightforward principles.

The histories, lives and worlds that shaped the development of competing ideas of recognition and their incidents are today firmly compressed. But the syllogisms were not always in these forms, the illustrations not always encapsulations, and declarativism and constitutivism not always the labels. Like all legal ideas, the concept of recognition has an important contextual background, and one which is easily forgotten or flattened in the focus on the logics of doctrine. That history is especially important because recognition involves a difficult blend of political

${ }^{1}$ In the Anglophone literature, see, among many others, J Dugard, Recognition and the United Nations (CUP 1987); C Warbrick, 'Recognition of States' (1992) 41 ICLQ 473; TD Grant, The Recognition of States: Law and Practice in Debate and Evolution (Praeger, 1999); S Talmon, Recognition of Governments in International Law (OUP 2001); S Talmon, 'The Constitutive versus the Declaratory Theory of Recognition: Tertium Non Datur?' (2004) 75 BYIL 101; M Shaw, International Law (CUP 2008) ch 9; M Craven, 'Statehood, Self-Determination and Recognition' in Malcolm Evans (ed), International Law (3rd edn, OUP 2010) 203; J Crawford, Brownlie's Principles of Public International Law (OUP 2012) ch 6; J Vidmar, 'Explaining the Legal Effects of Recognition' (2012) 61 ICLQ 361.

2 Note that most commentators quickly complicate the division beyond these schools: see, eg, Grant, Recognition of States, ch 1.

3 See International Law Association, 'Recognition/Non-Recognition in International Law' (ILA Report, United Nations, 2012). 
decisions and legal arguments. That blending provides one story in the immensely complicated history of changes in forms of political organisation and the interaction between political communities in the modern world. Within the broader history of international law, periods of upheaval and transition have always involved transformations in the entities that comprise the international order. The problem of transformation, today termed 'recognition', has always remained the same: how does an entity become part of the community beyond it, and who decides the criteria and judges its application?

In moving beyond general histories of recognition as a diplomatic problem ${ }^{4}$ or accounts of its development within international institutions and various courts and tribunals, ${ }^{5}$ this article presents a new perspective on the development of recognition. This history is built from the juristic works of British international lawyers. It tracks the conceptual changes between their works, places those shifts within their contexts, and shows how the political projects of jurists and states were woven into the purportedly 'logical' analytic propositions of recognition doctrines. Understanding the origins of recognition is important and urgent because that history is not a gradual, scholarly clarification of neutral criteria of statehood, or a simple description of diplomatic interactions and the reception of new states into an unblemished family of nations. This history shows how recognition was used to establish hierarchies of political communities, facilitating the exploitation of those placed at the bottom by those who placed themselves at the top. Nowhere is this plainer than in the writings of British jurists shaping and reacting to the rise and fall of the British Empire. The study thus contributes to the ongoing project of understanding the complicated and often problematic foundations of modern international law.

\section{B. Conceptual histories of international law}

This article's second, methodological contribution is to take up a conceptual history frame. ${ }^{6}$ Conceptual history examines the changing meanings, uses and contexts that shape the development of concepts, with a focus on their role in political and ideological debates within societies. Although ways of treating ideas, thought, philosophy, disciplines or intellectuals historically might be fairly termed 'conceptual history', today that specific formulation is most often directly associated with the

\footnotetext{
4 See, eg, M Fabry, Recognizing States: International Society and the Establishment of New States since 1776 (OUP 2010).

5 See, eg, Dugard, Recognition and the United Nations; Grant, Recognition of States; Talmon, Recognition of Governments.

6 The importance of engaging with historiography in constructing and writing international legal histories is explored in detail in 'Ambivalences, Anxieties / Adaptations Advances: A Historiography Manifesto' (Paper presented at Interest Group on the History of International Law, 'Evaluating the "Turn to History" in International Law', European Society of International Law $13^{\text {th }}$ Annual Conference, Naples, 6 September 2017).
} 
historical theories of Reinhart Koselleck. ${ }^{7}$ This article is guided by a Koselleckian mode of conceptual history. While a clear theory of this mode of historical work may be difficult if not impossible to articulate, ${ }^{8}$ several themes and methods can be discerned. ${ }^{9}$ It seeks to establish when an ordinary concept develops and emerges as a 'basic concept'. For Koselleck, concepts do not hold singular, unambiguous and clear meanings. Rather they hold multiple, controversial, contested meanings and connotations that accumulate as people use them to articulate or further political or social projects and ideals. When a concept becomes an 'inescapable, irreplaceable part of the political and social vocabulary' it may crystallise into a single term ('revolution', 'democracy'), and become a basic concept: simultaneously fluid, complex, controversial and contested in its usage by a range of political and social actors. ${ }^{10}$ A working definition of this difficult idea of 'basic concept' is an essentially contested and debated idea that is indispensable for the thought, articulations and actions underlying a wide spectrum of political projects within a particular national community.

Conceptual histories aim to trace this transition to 'basicness' by examining when, how and why particular strands of meaning are added to, persist in, or are discarded from a concept. To do so, they focus on language and context, examining which meanings remain stable in or across time, which meanings are chosen or promoted over time, and what contexts might explain these choices. The archive to which these methods are applied begins with the works of 'representative authors': the 'classical' texts of major philosophers, theologians, poets, legal and political theorists that use and debate the concepts examined. Scrutinising these major works reveals what Koselleck calls the 'semantic fields' of a concept: the conditions of possibility about what can be said, argued, understood and done at a particular time with that concept. Wider discussions in newspapers, periodicals, pamphlets, parliamentary debates, government sources, diaries, letters, and potentially dictionaries and

7 The major essay collections translated into English are R Koselleck, Futures Past: On the Semantics of Historical Time (K Tribe tr, Columbia University Press 1985); R Koselleck, The Practice of Conceptual History: Timing History, Spacing Concepts (TS Presner tr, Stanford University Press 2002). On the development of conceptual history, see, eg, M Richter, 'Conceptual History (Begriffsgeschichte) and Political Theory' (1986) 14 Political Theory 604; M Richter, 'Begriffsgeschichte and the History of Ideas' (1987) 48 Journal of the History of Ideas 247. The major, multi-volume 'encyclopedia' of conceptual histories is O Brunner, W Conze and R Koselleck (eds), Geschichtliche Grundbegriffe: Historisches Lexikon Zur Politisch-Sozialen Sprache in Deutschland (Klett-Cotta 1972-97). Note that 'Anerkennung' ('recognition'), even as a political/social concept, does not appear as an entry in the Geschichtliche Grundbegriffe, despite its importance for, eg, Fichte and Hegel's thought. For an introduction to Koselleck's life and work, see, eg, N Olsen, History in the Plural: An Introduction to the Work of Reinhart Koselleck (Berghahn, 2012); M Richter, The History of Political and Social Concepts: A Critical Introduction (OUP 1995).

8 See J-W Müller, 'On Conceptual History' in DM McMahon and S Moyn (eds), Rethinking Modern European Intellectual History (OUP 2014) 74.

9 For English translations of $G G$ entries, see F-L Knemeyer, 'Polizei' (1980) 9 Economy and Society 172; R Walther, 'Economic Liberalism' (1984) 13 Economy and Society 178. See also the recently translated prefaces: R Koselleck, 'Introduction and Prefaces to the Geschichtliche Grundbegriffe' (2011) 6 Contributions to the History of Concepts 1 .

10 R Koselleck, 'A Response to Comments on the Geschichtliche Grundbegriffe' in H Lehmann and M Richter (eds), The Meaning of Historical Terms and Concepts: New Studies on Begriffsgeschichte (German Historical Institute 1996) 59, 64; Müller, 'On Conceptual History', 84. 
encyclopedias, can be used to explore the limits of these fields. Importantly, conceptual histories focus on single national-linguistic traditions and communities: the meanings, histories, connotations and modes of communicating a concept are likely to be specific to say, England, France or Germany, even where terms appear similar or translatable on their face. ${ }^{11}$

The political, social and intellectual context of a period is not just a background to conceptual change. Contexts condition and shape a concept's various meanings and suggest the kinds of political projects, and the orderings, experiences and views of the world within those projects that a concept is used to describe and promote. ${ }^{12}$ The concrete 'facts' of history and language become relevant where a text uses, shapes, or is shaped by them. ${ }^{13}$ Facts and concepts do not necessarily change in synchronisation, but often at variable speeds: political realities might change faster than the ideas of the day, and conversely some conceptual innovations might appear before, or point towards, a future in which they could be realised. ${ }^{14}$ These variable speeds are contained in sub-periods of a hypothetical Sattelzeit ('saddle time') during which all basic concepts transition from 'traditional' to 'modern' forms, to operate in a new kind of historical time that allows them to describe actions and visions that change and re-make the world of the future - that is, to make political or social claims - rather than just describe the present. Drawing sub-periods within the Sattelzeit allows us to go beyond recording different meanings of words, concepts and their contexts, and to structure a set of thematic slices of time within which we can explore aspects of change and continuity in an episodic way. ${ }^{15}$

From all of these points, one useful general description of conceptual history is that it investigates four hypotheses about changes to a particular concept over time. The first is temporalisation: where, when and why do authors place a concept into a longer horizon of philosophical, historical or teleological development? The second is democratisation: where does the concept's audiences expand and extend beyond small, elite political classes? The third is ideologisation: at what point can a concept be generalised, abstracted and made usable by political groups? The fourth is politicisation: how do various actors use the concept to further their political projects amidst social, regional and national rearrangements and upheavals driven by revolution, war, economic change, or any other historical factor. ${ }^{16}$

This necessarily overbrief distillation of some approaches and methods of Koselleckian conceptual history should not be taken as a singular statement of what conceptual history is or must be. While that might be clear, it is worth emphasising for the purposes of this study. The aim of appreciating historical theory is not to construct a rigid set of requirements or demands without which we cannot do conceptual history.

11 See, eg, R Koselleck, 'Linguistic Change and the History of Events' (1989) 61 Journal of Modern History 649, 657-61.

12 Koselleck, 'Begriffsgeschichte and Social History', 419.

13 Koselleck, 'Introduction and Prefaces', 28.

14 On which, see Koselleck, Practice of Conceptual History, chs 7 ('Concepts of Historical Time and Social History') and 10 ('The Eighteenth Century as the Beginning of Modernity').

15 R Koselleck, 'On the Need for Theory in the Discipline of History' in Practice of Conceptual History, 1, 5.

16 These hypotheses were proposed in M Richter, 'Appreciating a Contemporary Classic' in Meaning of Historical Terms and Concepts, 12. 
Instead it serves as a set of deeper theoretical reflections for guidance through and adaptation to the methodological problems and difficulties of international legal history. ${ }^{17}$

What then might histories of concepts in international law look like? Given international law's reliance on wide swathes of the world of political ideas and movements, and the facts of the world, 18 several works in the history of international law have focused on concepts and ideas, though without adopting an explicit conceptual history methodology. ${ }^{19}$ Koskenniemi recently provided a short exploration of the enticing possibilities of conceptual history for international law, seeing it as a means of highlighting the 'polemical character of the vocabularies' of international legal arguments and their connection to political developments, and structuring a focus on polemical confrontations, the clash of opposing positions and approaching law in history 'narrated as an aspect of political struggle'. ${ }^{20}$

While these useful suggestions remain faithful to the general tenets of conceptual history, conflicts in international legal writings, despite their clear political agendas, rarely reach the rhetorical levels of polemical engagement (at least, this seems to be generally true in British works). This is partly because during the wider period of transition from traditional to modern concepts, international lawyers are formulating a scientific, technical and expert vocabulary. Polemical engagements would be highly revealing, and perhaps they can be more easily identified in sources beyond juristic texts. But given the general absence of polemic in representative works, I suggest a close attention to language, doctrine and contexts are the aspects of conceptual historical methods most closely relevant to international law.

The purpose of a conceptual history of international law is to identify the move from traditional, descriptive concepts to a modern form capable of being used for a range of competing political projects and different articulations of visions of the future through law. An initial list of concepts that are essentially contested and controversial, but simultaneously central to articulating arguments through international law could be generated from the headings of any major modern textbook: 'sources', 'sovereignty', 'treaty', 'general principles', and so on. 'Recognition' is perhaps now a basic concept par excellence: it is ordinarily introduced today by the supposedly diametric opposition of constitutivists and declarativists (and indeed, it is almost defined by that opposition), and it is perhaps more easily accepted as holding an important political dimension than other more traditionally 'legal' concepts in

17 See further Clark, 'A Historiography Manifesto'.

18 See, eg, M Koskenniemi, 'International Law in the World of Ideas' in J Crawford and M Koskenniemi (eds), Cambridge Companion to International Law (CUP 2012) 47.

19 Among them, ED Dickinson, 'Changing Concepts and the Doctrine of Incorporation' (1932) 26 AJIL 239; C Schmitt, The Nomos of the Earth in the International Law of the Jus Publicum Europaeum (Telos Press 2003); N Greenwood Onuf, 'International Legal Order as an Idea' (1979) 73 AJIL 244; C $\mathrm{Ku}$, 'The Concept of Res Communis in International Law' (1990) 12 History of European Ideas 459; A Carty, 'Myths of International Legal Order: Past and Present' (1997) 10 Cambridge Review of International Affairs 3; E Benvenisti, 'The Origins of the Concept of Belligerent Occupation' (2008) 26 Law and History Review 621. Schmitt's Nomos of the Earth is perhaps the clearest example. Schmitt's influence on Koselleck, incidentally, forms a significant link here: N Olsen, 'Carl Schmitt, Reinhart Koselleck and the Foundations of History and Politics' (2011) 37 History of European Ideas 197.

20 M Koskenniemi, 'A History of International Law Histories' in B Fassbender and A Peters (eds), The Oxford Handbook of the History of International Law (OUP 2012) 943, 968-69. 
international law. While general conceptual history sees basic concepts becoming historical when they move beyond technical, professional or aristocratic vocabularies (democratisation), a difficulty for international law is that conceptual change-at least in the nineteenth and early twentieth centuries - is most clearly illustrated by usage within the professional community of international lawyers, academics, judges, state leaders, officials or international bureaucrats, rather than wider or popular usage or understandings.

To respond to these particularities of international legal ideas, I shift the balance towards a closer attention to juristic texts as the main sites of likely conceptual change. As with general conceptual history, we should look for stability in meanings and connotations over time, changes recognisable at specific times, and the accretion and discarding of meaning likely seen in doctrinal endorsements, modifications, disagreements or criticisms. The contexts for placing these texts are those of their authors (personal, intellectual, political), the projects and visions of international law and society these texts describe or promote, and the concrete factual events that they are shaped by or seek to interpret or influence: diplomatic interactions, disputes, wars, treaties, trade, congresses, imperialism, colonialism, and so on. The central question is what kinds of meanings and projects were-or seemed - thinkable and realisable within the boundaries of law and legal ideas at the time, and how these texts expand those meanings or further those projects. General conceptual history's nationallinguistic strictures should be followed, but also for reasons of legal traditions. While cross-national conversations are common and important for the development of international law, many central building blocks of legal thought hold meanings and connotations specific to particular legal cultures (consider the widely different meanings of terms for law, right, justice, adjudication, constitution, state, international law, even within European traditions). Further, juristic texts have different forms, levels of authority, audiences and impact on practice depending upon the culture. Certainly, the dissemination, incorporation or resistance to 'foreign' legal ideas is important for conceptual history. But these interactions are best understood by examining their treatment in the texts of a particular national-linguistic legal tradition. As to time, as with general conceptual history the sub-periods should emphasise thematic changes in concepts, potentially overlapping, and be of sufficient length to allow the exploration of the frequently plural ways in which a concept transitions from traditional to modern forms. Here, I use 'strands' that link related jurists, projects and contexts that highlight different phases of changes in the concept of recognition.

Each of the Koselleckian theses noted above-temporalisation, democratisation, ideologisation, and politicisation — can be adapted to guide histories of international legal concepts. When might an international legal concept be placed into wider philosophical, historical or teleological narratives? When might it gain wider speakers and audiences beyond just the elite strata of jurists and state leaders? When might it be generalised or abstracted and then fitted into ideologies espoused by particular states or groups? And when might it become practical or usable for states or groups in articulating and pursuing political projects amidst the torrents of world history? After identifying the when, we may move to the how and why.

With these points on historiography in mind, this article proceeds as follows. Part II briefly notes the earliest reaches of recognition as a concept. Prior to the nineteenth century, recognition receives scant mention as a problem in English juristic works, and the first theories of recognition emerge in the writings of German jurists 
around 1760-1830. Part III presents the first strand of emergence and development of the concept from 1800-80 and the articulation of a 'traditional' or descriptive concept of recognition. The first British writings on recognition appear most clearly in textbook treatments by Robert Phillimore, Travers Twiss and WE Hall in the 1850s$80 \mathrm{~s}$. These texts present generalised criteria for recognition built from catalogues of intra-European diplomatic policies and strategies. This early concept stems almost solely from European concerns: either intra-European disputes over the status of new states, or stances towards European-style colonial entities in North and South America. Part IV examines a second strand from 1873-85 that emerges in James Lorimer's heavily theoretical works which, significantly, placed recognition at the foundation of the law of nations. Lorimer articulates a chauvinist, civilisational account that responds to the encounter between non-European empires and budding international law. Lorimer's work systematically integrates Christianity and civilisation into the concept of recognition to further his project of resisting the gradual, seemingly inexorable need to extend some form of recognition to the major imperial states of the Ottoman Empire, Japan and China. Part V considers a third strand from 1885-1914 that moves recognition's racialized aspects to imperial and colonial projects, commencing with the Berlin Conference of 1885 and illustrated in the works of Twiss and especially John Westlake. These works seek to sanitise the chauvinist elements in Lorimer's thinking by shifting recognition's focus to ostensibly 'neutral' legal ideas about government, representation, treaty-making, and territorial control. Texts by Westlake and Twiss on 'primitive' political communities that recognise their international personality only insofar as that recognition can facilitate colonial exploitation, introduce new meanings and connotations into the term. Lassa Oppenheim's challenging new concept of recognition in 1905 purportedly removes the chauvinist superiority of European civilisation by shifting away from characteristics of states or civilisational characteristics towards a central emphasis on acceptance by current members of the society of nations, on whatever basis they choose. Part VI presents a final strand of 1915-50, exploring the contestation between concepts of recognition in the works of John Fischer Williams, Thomas Baty and Hersch Lauterpacht. Each of these jurists try to reconfigure recognition's place in the new international system of the League of Nations, drawing on or rejecting ideas associated with the earlier strands of thinking and advancing new meanings tied to political and utopian projects. In doing so, they illustrate the emergence of recognition as a basic concept in international law. Part VII succinctly considers how writings of the 1950s reflect recognition's status as a basic concept, and why, with the collapse of the British Empire and the shifting focus for recognition questions to the United Nations, the concept of recognition is no long a central frame for political projects of exclusion or marginalisation, as the decolonising world turns to a new international law and selfdetermination.

\section{EARLIEST REACHES OF THE CONCEPT OF RECOGNITION}

There are several views of the emergence of recognition as a 'problem' of international law. One view emphasises legitimacy and authority, and locates recognition's nascent form in papal recognitions of the fifteenth century; the Pope's blessing of a Christian prince's rule was a necessary and constitutive acknowledgement of his status as an independent member of the 'club' of Christian 
nations. ${ }^{21}$ During this time throughout Europe, a declaration of heresy or tyranny by the Pope could legitimise both external wars waged by neighbouring princes and the internal wars waged by a prince's subjects who were no longer bound to recognise his claim to divine right: when papal use of this power threatened European peace, sovereigns and their jurists looked to alternative groundings of legitimacy, and a struggle between temporal (civil) and spiritual (papal) jurisdiction ensued. ${ }^{22}$ Another perspective focuses on the emergence of independence and sovereignty as characteristics of statehood. The 1581 declaration of independence by the Netherlands constituted, for Frowein, the first 'important problem' of recognition, eventually resolved only with formal Spanish recognition in 1648, with the Holy Roman Emperor, in the meantime, suggesting that full sovereignty for the Netherlands could only be granted by Spain. ${ }^{23}$ On either account, intra-European political struggles produce the early problems of recognition.

The first conceptual debates about the nature and meaning of recognition appear in German juristic writings of the 1760s onwards. In Alexandrowicz's stillvaluable account, early works were prompted by waning papal and imperial authority and the rise of elective monarchies, and, later, the secession and independence of the United States, while later works responded to entrenchment of the Great Powers as the arbiters and interpreters of the criteria of recognition under the system grounded in the Congress of Vienna. ${ }^{24}$ Concepts of recognition in these works gain their meanings from attempts to debate, explain and justify various changes in states within Europe and their colonies and in the overall system of international relations in the Vienna period. German theorising was preoccupied with explaining the role of law in these diplomatic contests. Now that the 'society of nations' held unchallenged power to respond to mutual problems between the Great Powers through congresses and the evaluation of revolutions, secessions and new states, it became clear that membership of that society was paramount for international political efficacy. These earliest concepts of recognition are far from crystallised or ordered into a clear set of criteria or principles. They are often composed on the foundation of other international legal ideas: independence, sovereignty, equality, intervention, legitimate authority. And these concepts, in turn, are used without clear definitions, often illustrated through specific examples of secessions, interventions and revolutions.

While the works of jurists in the British Isles from the sixteenth century onwards are certainly steeped in these problems of recognition-papal authority, the structure of the Holy Roman Empire and other imperial polities, the independence of the Netherlands, the Peace of Westphalia, and so forth, ${ }^{25}$ - the term 'recognition'

21 WG Grewe, The Epochs of International Law (De Gruyter 2000 [1984]) 75-82; HM Blix, 'Contemporary Aspects of Recognition' (1970) 130 Recueil des Cours 587, 604ff.

22 A Orford, International Authority and the Responsibility to Protect (CUP 2011) 140.

23 See JA Frowein, 'Transfer or Recognition of Sovereignty-Some Early Problems in Connection with Dependent Territories' (1971) 65 AJIL 568.

24 CH Alexandrowicz, 'The Theory of Recognition in Fieri' (1958) 34 BYIL 176.

25 Perhaps best reflected in R Zouche, An Exposition of Fecial Law and Procedure, or of Law between Nations, and Questions Concerning the Same, Wherein Are Set Forth Matters Regarding Peace and War between Different Princes or Peoples, Derived from the Most Eminent Historical Jurists (TE Holland tr, Carnegie Institution 1911 [1650]). 
appears only at brief moments and never within an extended theoretical treatment. ${ }^{26}$ Alberico Gentili's works of the late sixteenth and early seventeenth centuries, for example, contain several references to 'recognising' the right to send ambassadors inhering in lawful enemies, foreign laws, and various kingdoms and imperial sovereigns, and punishments due to rebellions against 'recognised' authority. ${ }^{27}$ Yet Gentili never treats recognition directly as a concept. The English text of John Selden's $O f$ the Dominion of the Seas does use the term 'recognition' explicitly, albeit in relation to French and Flemish 'acknowledgements' of England's 'sea dominion', 28 rather than in relation to sovereignty, subjectivity or government, and without any extended discussion or explanation of his meaning. Richard Zouche's major treatise of 1650 contains a wider range of meanings of recognition more readily similar to today's variety of uses - of the law of nations itself, of titles, of kings recognised by sending ambassadors, of the superiority of particular sovereigns or emperors, and of free peoples. ${ }^{29}$ Despite this wider range of uses, Zouche, like Gentili, uses these as brief illustrations of particular legal questions and disputes, and does not treat recognition itself as a concept in need of definition or direct consideration.

English works in the late eighteenth century, mostly written by the politicianlawyers of the era, were more interested in questions of national policy than intellectual arguments on legal doctrine that preoccupied German jurists located within universities. ${ }^{30}$ The first volume of Blackstone's Commentaries on the Laws of England of 1765, with its brief but influential considerations on the law of nations, mentions recognition at several points though in relation to the recognition of domestic sovereignty within English public law, rather than foreign sovereigns or states within the law of nations; for example that parliament 'doth not, nor ever did, recognize any foreign power, as superior or equal to it in this kingdom', 31 and in relation to the

\footnotetext{
26 There is a risk of anachronistic translation in using the early twentieth century English translations of these works. The Latin texts of Gentili and Zouche tend to use agnitio (a recognition, a knowledge, acknowledgment, understanding, knowing, admission, acceptance) rather than recognitio (a reviewing, investigation, examination; the Latin root of the early modern English word that was also partly derived from French), which appears only rarely. See CT Lewis \& C Short, A New Latin Dictionary (OUP 1891) 73 (agnitio) and 1534 (recognitio). In some instances, 'recognition' seems to have been inserted by the translator because the context related by the original authors would correspond, in the early twentieth century, to an issue of recognition. Yet because neither Gentili nor Zouche propose what might be a solid proto-concept of recognition, this risk is relatively unimportant.

27 A Gentili, De Legationibus Libri Tres (GJ Laing tr, OUP 1924 [1594]) vol 2, 79; A Gentili, Hispanicae Advocationis Libri Duo (FF Abbott tr, OUP 1921 [1661]) vol 2, 71 (non-recognition of Justinian's Code); A Gentili, De Iure Belli Libri Tres (JC Rolfe tr, Clarendon Press 1933) vol 2, 26 (of the Kingdom of Spain), 117 (papal acquiescence to Greek emperors until Charles), 320 (rebellions).

28 J Selden, Of the Dominion, Or, Ownership of the Sea (1652) bk II, chs xxvii and xxix.

29 Zouche, Exposition of Fecial Law, 1 (law of nations itself); 10, 25, 62, 82, 84 (sovereigns); 17, 67 (titles); 19 (by ambassadors); 63, 64, 119 (free or independent peoples).

30 See D Armitage, 'Parliament and International Law in the Eighteenth Century' in Julian Hoppit (ed), Parliaments, Nations and Identities in Britain and Ireland 1660-1850 (Manchester University Press 2003) 169, esp 179-81; DHN Johnson, 'The English Tradition in International Law' (1962) 11 ICLQ 416, 431-39.

31 W Blackstone, Commentaries on the Laws of England (Clarendon Press 1765) vol 1, 79.
} 
recognition of divine right in the monarch, eventually effected by parliament alone. ${ }^{32}$ Jeremy Bentham's 'The Principles of International Law', composed in the late 1780s and posthumously collated and published in the $1840 \mathrm{~s}$, notes that the refusal of recognition of 'the right of a newly-formed government' had been a 'frequent cause of war' and places it under the heading of foreign involvement in 'intestine troubles'.33 Bentham does not consider its meaning, despite lengthy examinations of the terms 'sovereignty' and 'dominion'. 34 Ward's 1795 history only mentions recognition briefly in relation to the recognition of royal rank and titles of dependent kingdoms within England and Spain. 35 Sir James Mackintosh's frequently re-issued and influential Discourse on the Study of the Law of Nature and Nations, which replicated the introductory lecture to his 1799 lectures on the law of nations, at Lincoln's Inn, does not explicitly mention 'recognition' among a long and detailed (though not exhaustive) catalogue of the subjects to be covered in the series. 36

\section{ReCognition AND Diplomacy: CATAlogues of EuRopean PoliCy IN PHILLIMORE, TWISS AND HALL, 1800-80}

Perhaps ironically, Mackintosh's parliamentary speech on Britain's recognition policy towards the South American republics in 1824 was heavily influential in shaping doctrines of recognition used by a range of governments. ${ }^{37}$ This statement accompanied the presentation to Parliament of a petition by the merchants of the City of London, who sought to open trade with these new republics. ${ }^{38}$ In that speech Mackintosh insisted on two meanings of recognition: a 'technical term of international law' meaning the 'explicit acknowledgement of the independence of a country by a state which formerly exercised sovereignty over it', and virtual recognition, 'not by formal stipulations or solemn declarations ... but by measures of practical policy, which imply that we acknowledge [the new state's] independence'. 39 While the speech is frequently cited in juristic works that articulate the first British concepts of recognition, these do not begin to appear until the mid-nineteenth century.

32 Ibid, 98 (in relation to the dependent territory of Ireland and Henry VIII), 198-202 (in relation to Henry VII, Mary, Elizabeth and so on).

33 J Bentham, 'Principles of International Law (1786-9)' in John Bowring (ed), The Works of Jeremy Bentham (Tait 1843) vol 2, 535, 545.

34 See further M Janis, "Jeremy Bentham and the Fashioning of "International Law" (1984) 78 AJIL 405.

35 R Ward, An Enquiry into the Foundation and History of the Law of Nations in Europe, from the Time of the Greeks and Romans to the Age of Grotius (Butterworth 1795) vol 1, 417-19.

36 These topics are outlined in J Mackintosh, A Discourse on the Study of the Law of Nature and Nations (2nd edn, Caddell, Davies, Derrett and Clarke 1799) 98. The other 38 lectures were not published.

37 See, eg, I Van Hulle, 'Britain's Recognition of the Spanish American Republics: The Gap between Theory and Practice in International Law (1810-1900)' (2014) 82 Tijdschrift voor Rechtsgeschiedenis 284; Fabry, Recognizing States.

38 J Mackintosh, 'Speech on Presenting a Petition from the Merchants of London for the Recognition of the Independent States Established in the Countries of America Formerly Subject to Spain' in J Mackintosh, The Miscellaneous Works of the Right Honourable Sir James Mackintosh (Phillips, Sampson and Co 1854) 549, 549-50.

39 Ibid, 559. 
Mackintosh's language of explicit and virtual recognition is taken up by Phillimore and Hall in particular.

Within this first strand, recognition is initially described in diplomatic, descriptive 'factual' theories that rely on catalogued histories of intra-European diplomatic disagreements - the independence of the United States, newly-independent Spanish American Republics, Congress of Vienna-era disputes and independence movements in Belgium and Greece, and the US Civil War-and endorse British state practice and diplomatic statements largely uncritically. It is only in major textbooks from the 1850s onwards that recognition is treated as a distinct concept and given content largely through generalisations about similarities between various diplomatic incidents that are used to illustrate its meaning. Where non-European states are considered, they are not yet seen as posing a specific challenge for recognition, but rather are treated - often briefly-under the concept of statehood.

I describe the style of writing and argument in the texts examined in this Part as a 'catalogue'. These works closely explore the factual detail of various incidents and changing policies, and draw strong links between recognition and intervention. And while they cite and draw on the German juristic writings noted above, and are likewise focused on intra-European diplomacy, they largely resist any speculative or systematic consideration of the nature of recognition itself. 'Catalogue' also echoes the important contextual point that during this time British writing on international law was far less systematic than its German-language predecessor-counterparts, owing to differing traditions of legal practice, the minor role played by university instruction and research in international law in the early decades of the nineteenth century, and the admixture of civil and common law traditions in British courts when dealing with questions of international law prior to the $1870 \mathrm{~s} .40$

\section{A. Early writings}

The barrister Frederick Eden's (1784-1823) Historical Sketch presents the first brief examination of the concept of recognition in a British juristic text, and its first use in a polemical pamphlet. Published in 1823, citing inspiration from Mackintosh's lectures, and dedicated mostly to using history to condemn the 'outrages' of Napoleonic France against the law of nations and purportedly 'ancient' principles of 'international policy', ${ }^{41}$ Eden's work presents a British perspective on Congress-era recognition issues, read as debates over legitimism and intervention. He defends Britain's refusal to sanction Austria, Russia and Prussia's 'Declaration in Favour of Legitimacy' of 8 December 1820, which asserted a general right of intervention against revolutionary movements they deemed a threat to European peace, and endorses this position by reference to the nature of recognition. He reads the Declaration as 'resolv[ing] itself into a recognition of hereditary Succession upon the ancient footing, on which it existed in Europe, and a solemn protest against the opposite principles'. ${ }^{42}$ That use of

\footnotetext{
40 See, eg, JA Carty, Nineteenth Century Textbooks and International Law (PhD thesis, University of Cambridge 1973); C Sylvest, 'International Law in Nineteenth-Century Britain' (2005) 75 BYIL 9.

41 See F Eden, An Historical Sketch of the International Policy of Modern Europe as Connected with the Principles of the Law of Nature and of Nations Concluding with Some Remarks on the Holy Alliance (Murray 1823) 83ff.

42 Ibid.
} 
recognition, he urged, was 'subversive of Public Law and of the independent existence of Nations' because it justified foreign interventions and assistance to preserve 'the power of Sovereigns at the expense of the just privileges of their subjects, and of that original and inherent right of resistance and self-defence'. ${ }^{43}$

Eden continues his castigation of the Alliance by examining several other meanings of recognition. The Alliance's decision, following the Neapolitan and Spanish revolutions of 1820 , to 'refuse to recognize those reforms which were either adverse to the Monarchical Principle, or which did not emanate from Thrones' - that is, contrary to hereditary succession, or not granted by monarchs - established a purported right of intervention not to prevent actual danger but only to stop 'the establishment of a form of government inconsistent with their own views and interests'. ${ }^{44}$ This use of recognition, urged Eden, was contrary to the 'imprescriptible right' of all nations to select their own constitutions, the changes to which would nonetheless not prevent states from maintaining the 'usual relations of peace and amity' or the 'ancient federal maxims of the European Commonwealth' that preserved independence regardless of national strength. 45 This 'unwise policy', though it had not yet 'corrupted' Europe's public law, threatened to undermine its system of federal relations 'so essential to the security and happiness of mankind'. ${ }^{46}$ Eden concludes his Sketch with the mention of a new spectre:

the wide diffusion of knowledge, and the constant communication among the European states, has not only given every Nation a clearer insight into her real interests, but has introduced a new principle in politics, unknown to ancient times, in the salutary and effectual controul [sic] which Public Opinion has long exercised even over the most ambitious and enterprising Princes. ${ }^{47}$

The foregoing, and this conclusion in particular, reinforces the central concern for Eden's rather unsystematic set of views on recognition's nature: that recognition should not be used as a tool of intervention into internal government changes, partly because European integration and peace relies on non-intervention, and because public opinion's 'effectual controul' is increasingly curtailing the unilateral actions of monarchs through the demands of popular representation. Eden's work was far less systematic than that of his German predecessors, and was not cited or discussed in later treatments. Nonetheless it is intriguing because it reflects a set of views about legal restrictions on recognition tied very closely to the international political projects of the day.

Despite the publication of new textbooks and treatises in Britain from the $1830 \mathrm{~s}-50 \mathrm{~s}$, in a (perhaps minor) 'renaissance' of international legal scholarship in Britain, ${ }^{48}$ these works devote no ${ }^{49}$ or minimal ${ }^{50}$ attention to recognition. These texts

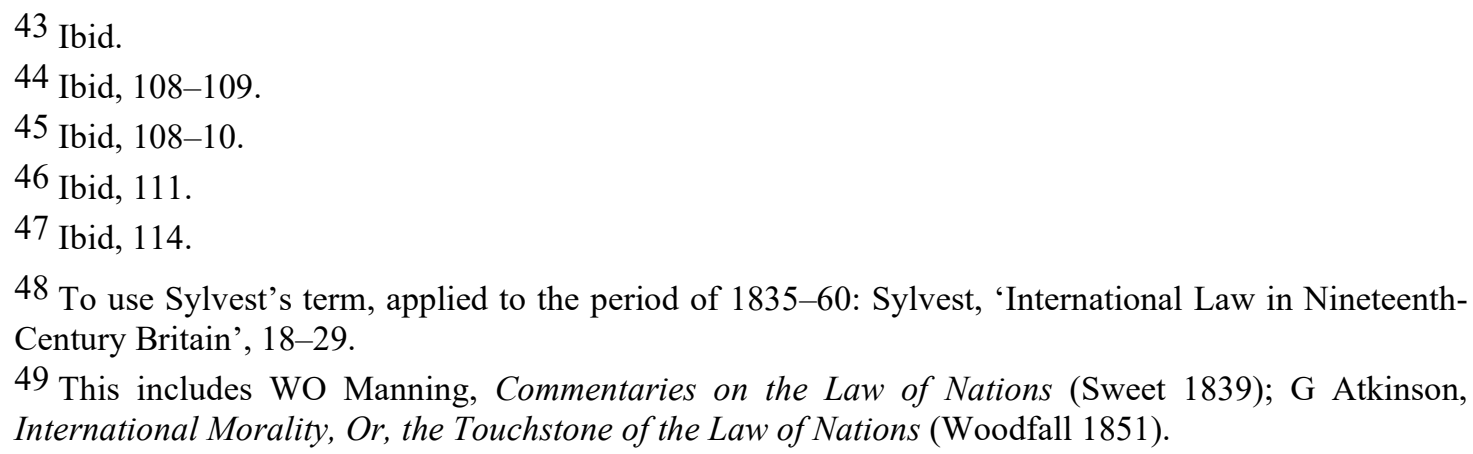


are mostly written by authors with doctoral qualifications who held membership of the Doctors Commons, teaching appointments in new university law programs, or government advisory posts. They tend to be directed not only at university audiences but also practitioners, the interested public, and, more importantly, statesmen dealing with international relations, to whom they were often dedicated. ${ }^{51}$ Despite treating a range of topics systematically, the few that do mention recognition at all make short general statements illustrated briefly by European diplomatic incidents.

The first holders of the new English chairs in international law-the Chichele at Oxford, held by Montague Bernard (1820-80) from 1859 and the Whewell at Cambridge, held by William Harcourt (1827-1904) from 1869-both wrote on belligerent recognition. Yet these works explored the difficulties arising from diplomatic practice during the US Civil War. They attempted to distil principles of recognition from that practice, rather than propose any systematic conceptual treatment of the concept. Bernard's detailed history of Britain's neutrality during the Civil War briefly considered the question of recognition of belligerency but focused closely on its application to the details of the conflict, with no sustained attempt to clarify or test a general meaning of recognition. ${ }^{52}$ Harcourt's well-known letters to The Times under the pseudonym 'Historicus', published in the 1860s while he was still at the Bar in an attempt to educate the British public on questions of international law, are similarly practice-focused but are more revealing than Bernard's brief consideration. In the preface to an 1863 collection of the letters, Harcourt explains that they 'attempt to ascertain the true principles by which the recognition, on the part of foreign Governments, of insurgent communities, is governed' and notes that on this question 'but little precise information will be found in the ordinary text-books'. 53 What makes recognition such a difficult problem is the tension between law and policy, a distinction Harcourt wrote was vastly 'important' and yet very likely to 'confound': in practice '[p]olicy might possibly suggest that which law nevertheless disallows [and] law might permit what policy, notwithstanding, would dissuade'.54 For Harcourt, the legal principles governing recognition flow from the independence of sovereign states and the obligations of mutual respect for sovereignty, which he took to imply a right to the 'obedience of subjects' regardless of governmental type. ${ }^{55}$ Consequently, dealing with insurgents 'on a footing of independence' is a hostile act

50 A Polson, Principles of the Law of Nations (Griffin,1848) 26-27 (on recognition of titles) and 99 (on recognition of diplomats); R Wildman, Institutes of International Law (Johnson 1850) vol 1, 56-57 (on the reception of ambassadors as recognition of sovereignty) and 89 (on recognition of imperial title), vol 2, 78-79 (on recognition of the fact of partial loss of dominion to insurgents); James Reddie, Inquiries in International Law, Public and Private (Blackwood 1851) 185-86 (non-recognition of domination as freedom, recognition of insurgencies).

51 On these points, made in relation to Phillimore, see A Carty, Philosophy of International Law (Edinburgh University Press 2007) 10-11.

52 M Bernard, A Historical Account of the Neutrality of Great Britain during the American Civil War (Longmans, Green, Reader and Dyer 1870) 107-17.

53 WV Harcourt, Letters by Historicus on Some Questions of International Law, Reprinted from 'The Times' with Considerable Additions (Macmillan 1863) 1.

54 Ibid, 3.

55 Ibid. 
that violates the sovereign right of dominion. 56 The question of when a subject ceases to be a subject 'is a question of mixed law and fact' lacking an easy solution, and general statements are of less use, he thinks, than detailed examinations of practice: 'The answer is to be looked for rather in the recent and approved practice of nations than in any definitions of text books'. ${ }^{57}$ Following a review of the instances of Belgium and Greece, cast as interventions, and Canning's policy on the South American republics, seen as 'true cases' of recognition rather than interventions, Harcourt concludes that the 'practical rule' seems to be that when the mother state has 'virtually and substantially abandoned the struggle for supremacy', it can no longer assert its right to complain when another state recognises the independence of the insurgents as established: 'The true rule is that laid down in the old distich. Rebellion, until it has succeeded, is Treason; when it is successful, it becomes Independence. And thus the only real test of independence is final success'. 58 Bernard and Harcourt's works are not systematic treatments of the concept of recognition, but rather attempts to clarify confusions about its nature, prompted by political debates about whether Britain should recognise the Confederate States. Meanwhile, however, more theoretical illustrations of early theories of recognition appear in the texts of Phillimore, Twiss and Hall.

\section{B. Phillimore and Twiss}

Despite Phillimore's political experience in both domestic and international matters, as well as his considerable legal learning, ${ }^{59}$ his Commentaries of the mid-1850s were criticised (by Harcourt) as an excessively long and 'indiscriminate digest of opinions' lacking any 'scientific investigation of the principles and practice of international law'. 60 Although this criticism is arguably well illustrated by Phillimore's account of recognition, Phillimore's treatment of recognition in volume 2 (1855) remains innovative and intriguing. It presents the first systematic articulation of the concept of recognition in a British international law treatise.

For Phillimore recognition is 'closely connected' to the topic of intervention. Its 'usual meaning' is 'a kind of moral intervention by one State into the affairs of another'. ${ }^{61}$ Phillimore does not expand on precisely what he means by 'moral', but he seems to suggest the freedom of states to make their own decisions on the basis of policy (and possibly as a contrast to interventions based on legal arguments). He then turns in detail to a second meaning: recognition may also signify a mother country's acknowledgement of a successful secession by a province and its attainment of independent statehood. Phillimore offers a long line of European historical

\footnotetext{
56 Ibid.

57 Ibid, 4.

58 Ibid, 9-10.

59 See Sylvest, 'International Law in Nineteenth-Century Britain', 27-29, concluding that Phillimore's work 'paradoxically, both blurs and upholds the distinction between domestic and international politics'.

60 Harcourt, Letters by Historicus, vii.

61 R Phillimore, Commentaries upon International Law (Johnson 1855) vol 2, 31. Phillimore cites in support Martens, Klüber, Oppenheim, Saalfeld, Wheaton, Heffters [sic] and Vattel.
} 
examples - German and Spanish recognition of the Swiss cantons and the Netherlands in 1648, Spain's recognition of Portugal in 1713, Britain's recognition of the United States in 1783, and France's recognition in 1815 of various kingdoms formerly conquered by Napoleon - that effectively involve the relinquishing of an imperial claim by a European state to a particular province. ${ }^{62}$ Recognition by third powers, however, is the more pressing topic. To Phillimore it arises in only three instances: where a nation acquires a new territory which it claims to have recognised as an 'integral part of her kingdom'; when a province claims independence and seeks admission as an independent community into international society; and where a governor of an independent state assumes a new title and claims recognition by other states of it. ${ }^{63} \mathrm{New}$ acquisitions belong 'more properly' to questions of belligerency, neutrals and effects of war. 64

Phillimore then focuses most closely on this second instance of revolutions, endorsing Mackintosh's 1824 distinction and dividing recognition into the virtual and the formal. Virtual recognition is a third power decision to remain neutral but to recognise the commercial flag of the putative state and to appoint consuls to its ports. This is 'a Recognition of [the putative state's] de facto existence, fully justified, perhaps indeed imperatively enjoined, by the duties of the Third Power towards its own subjects': that is, the third power should not frustrate its own subjects' ability to trade, which was the impetus for Mackintosh's speech on recognition. 65 Over time, virtual recognition gives way to formal recognition, evidenced in sending ambassadors and entering into treaty relations with the new state. Before this 'grave step' can be taken, though, 'two facts should occur': the practical cessation of hostilities by the mother state, and, more substantively, the consolidation of the new state. 66 'Consolidation' here means the maintenance of diplomatic relations with other countries and the possession of 'absolute bona fide' independence as a separate kingdom. Independence does not require 'perfect and undisturbed internal tranquillity' but rather a government, acknowledged by the people it governs, that is 'ready and able to acknowledge and prove its responsibility for their conduct when they come into contact with foreign nations'.67 The government's representativeness or type is irrelevant: its ability to control or be held responsible for the conduct of its citizens overseas is what matters. Where this kind of government exists, the question of formal recognition 'concerns the internal policy of other kingdoms' and is not 'a question of an International character'. 68 Once these facts are known, then even the mother state's refusal to recognise is no 'legitimate bar to the complete and Formal Recognition of the new State by other communities of the world' ${ }^{69}$ Phillimore moves to consider a range of instances of this within Europe and the Americas, dissecting and endorsing

62 Ibid.

63 Ibid.

64 Ibid, 32.

65 Ibid.

66 Ibid, 34.

67 Ibid.

68 Ibid.

69 Ibid. 
the statements made in the 1820 s by the British Ministers Mackintosh and Canning on the Spanish South American Republics. ${ }^{70}$

Sir Travers Twiss's (1809-97) The Law of Nations Considered as Independent Political Communities (1861) also focused on European political changes in its description of the nature of the state and the role of recognition in the international community. Twiss was called to the bar in 1840, held the Drummond Chair in political economy at Oxford from 1842-7 and published extensively on European history, political economy and the progressive development of communities in Europe. ${ }^{71} \mathrm{He}$ held a chair in International Law at King's College from 1848-54, and was then appointed the Regius Professor of Civil Law at Oxford in 1855, holding the post until $1870 .^{72}$ For Twiss, recognition is specifically recognition of a nation's independent existence.

Whereas Phillimore did not cover recognition until the second of his threevolume Commentaries, Twiss deals with it as a central concept in the early pages of his Law of Nations. After explaining his views of the nature of international law and its subjects and placing 'the nation' at the foundation of international law, Twiss ties his concept of recognition to the independence of the nation: independence and nationhood form the basis of membership of the international community. ${ }^{73}$ Contrary to the fixation on states, nations and the international community that Twiss perceives in the ancient authorities and Grotius, Pufendorf, Wolff and Vattel, ${ }^{74}$ Twiss defends his preference for nations and independence by drawing a close parallel between domestic and international aspects of polities and organisation in their general forms. Mimicking national societies, international society is simply 'the most enlarged phase of Natural Society' in which nations are collective and representative bodies that aim to hold 'intercourse with other like Bodies of men through the medium of the State'. ${ }^{75}$ Internal organisation is 'immaterial', provided that it acts to represent a nation's citizens or subjects. ${ }^{76}$ And as in the domestic state, freedom and independence from others is necessary: at the international level 'Independence is accordingly the fundamental element which imparts to a State the character of a Nation'. ${ }^{77}$

Twiss then moves to consider recognition as a procedure of membership. Admission to the fellowship of nations occurs either by 'overt' recognition of this independence by a public act by the 'Established Powers', or 'tacit' recognition in 'being allowed' to become a contracting party to a treaty with those powers. ${ }^{78}$

\footnotetext{
70 See Van Hulle, 'Britain's Recognition of the Spanish American Republics'.

71 See T Twiss, View of the Progress of Political Economy in Europe since the Sixteenth Century (Longman, Brown, Green, and Longmans 1847); On Certain Tests of a Thriving Population: Four Lectures (Longman, Brown, Green, and Longmans 1845).

72 See T Twiss, Two Introductory Lectures on the Science of International Law (Longman, Brown, Green, and Longmans 1856).

73 T Twiss, The Law of Nations Considered as Independent Political Communities (OUP 2 vols, 18613) vol 1, 1. Twiss defines nations as groups with 'ties of a common lineage and perhaps a common language', and as societies within a common territory united under a government.

74 Ibid, 2-6.

75 Ibid, 8.

76 Ibid, 8, see also at 16.

77 Ibid, 9 (emphasis in original).

78 Ibid.
} 
Rejecting Hobbes' narrower view that independence is demonstrated by the ability to defend against external attacks, Twiss concludes instead that independence, absolute 'and not subject to qualification' means the absence of any de jure dependence 'upon any other State for its freedom of political action'. Consequently all nations are 'Peers and Equals' regardless the factual differences in power between them. ${ }^{79}$

For Twiss, it is the 'quality of Independence' that, upon its assertion by a nation, requires the recognition of other nations. ${ }^{80}$ Taking former dependencies as his main example, Twiss contends that when that body 'seeks to hold international intercourse with other States, and claims to be received into the fellowship of Nations upon terms of equality and reciprocity with other nations', then it first requires their recognition of its independence. ${ }^{81}$ Other nations remain free to grant or withhold that recognition, and Twiss foresees that each will do so on a prudential basis of weighing the relative 'hostilities' which a recognising state might incur from either the mother state or the new nation. ${ }^{82}$ Underlying this view of recognition is Twiss's strong rejection of the relevance of internal constitutional orders or legitimacy standards for nationhood, 83 and his rejection of Vattel's 'combining Sovereignty with Independence as the criteria of Nationality; for Sovereign States are not necessarily Nations, while States internationally independent are not always Sovereign Powers'. $84 \mathrm{He}$ also disapproves of the terminology of 'semi-sovereign' and prefers instead to couch examples of states under partial suzerainty (such as those within the Holy Roman Empire) to degrees of independence and protection rather than sovereignty: weaker states under arrangements of protection are dependent if they do not maintain separate relations with other states besides their protector. Twiss raises the 'Native States of India' as examples of protected dependent states, in that each acknowledges the supremacy of the British Government and none has any interaction with one another or foreign powers.

Both Phillimore and Twiss's works and concepts concentrate on intraEuropean and American recognition questions. Their publication dates also straddle the Crimean War (1853-6), which Russia lost to an alliance of Britain, France and the Ottoman Empire. The subsequent peace agreement, the Treaty of Paris (1856), significantly made the first 'admission' of the Ottoman Empire as a non-European power to the European system of international law, allowing it to 'participate in the advantages of the Public Law of Europe'. Although the precise meaning and consequences of this admission remained debated, it was a significant pivot by the international legal system towards Europe's periphery that could not be long ignored by jurists. 85 Phillimore and Twiss, here and in successive editions, do not consider the engagement with non-European entities as relevant for their concepts of recognition.

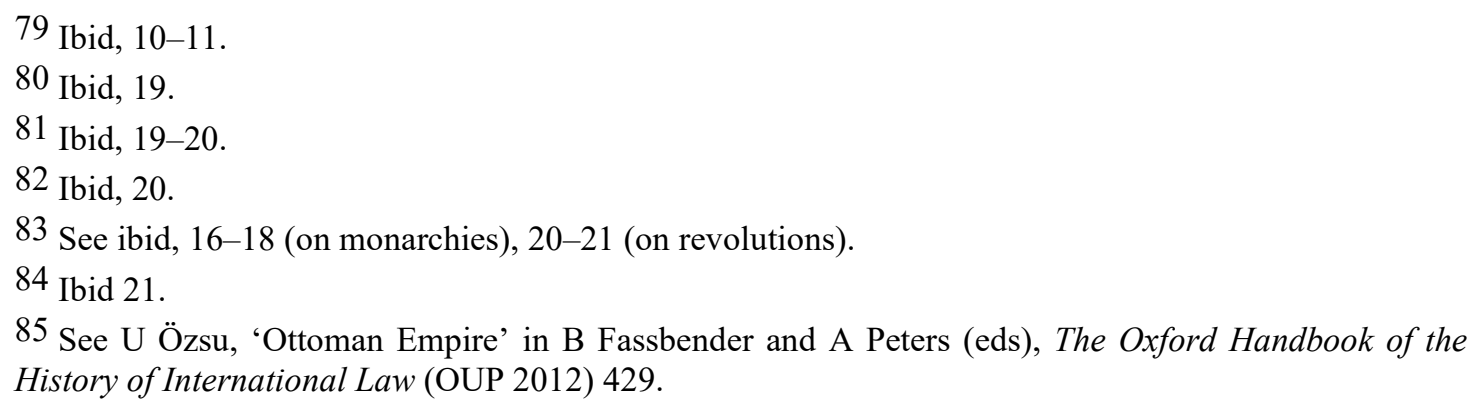


They address the encounter with Europe's periphery as a general question about the nature of states, rather than recognition.

In Phillimore's volume 3 of 1857, the Ottoman Empire's entry into the international community is acknowledged as 'beyond all doubt', ${ }^{86}$ but neither the second edition of 1871 nor the third edition of 1882 explicitly consider that entry in relation to recognition. Yet Phillimore perhaps makes some subtle amendments of acknowledgement. Both the 1871 and 1882 texts examine only intra-European questions of recognition, albeit with a stronger statement that internal systems of government, provided they do not threaten other states, are no concern of international law. Phillimore now begins, however, with a nod towards newly established states that might not adhere to international law:

when a new State springs into being, and demands to be admitted into the great commonwealth of States, International Law requires that her political status be so far considered by other States, as to satisfy them that she is capable of discharging international obligations. The Recognition of the new by the old States signifies their conviction that she possesses such capacity. ${ }^{87}$

At this point Phillimore reiterates recognition's closeness with intervention as a 'kind of moral intervention'. Whether or not this is a subtle reference to the Ottoman Empire's recent admission, Phillimore clearly sees no need to ruminate further on the significance of new states 'springing' into being or to modify his idea of recognition, beyond mentioning this requirement of adherence to international law.

But whereas these developments do not bear on Phillimore's concept of recognition, he treats them as relevant for his concept of the state. ${ }^{88}$ Noting that international law 'has no concern' with questions of internal government, religion, or the power of a state, ${ }^{89}$ Phillimore notes in his first volume of 1854 that eighteenthcentury treaties with African kingdoms evidenced that European states 'acknowledg[ed] and confirm[ed] to them the relations of legal communities'. $90 \mathrm{He}$ cites Lord Stowell's view that while African notions of 'international justice' differ, European states would still treat these kingdoms as having the rights and duties of states, albeit sometimes requiring a 'relaxed application' of some principles of international law. ${ }^{91}$ This applies equally to the Ottoman Porte, which despite its diversity and inclusion of Christian nations (whose 'origin, manners, and institutions' and 'above all' religion distinguish and 'eternally separate [them] from the Turk' ${ }^{92}$ ), had entered into extensive treaty relations with European states. ${ }^{93}$ Consequently, 'the Porte must now be considered as subject, with only such exceptions as the reason of

86 R Phillimore, Commentaries upon International Law (Johnson 1857) vol 3, iii.

87 R Phillimore, Commentaries upon International Law (2nd edn, Butterworths 1871) vol 2, 16 (emphasis in original); Commentaries upon International Law (3rd edn, Butterworths, 1882) vol 2, 20 (emphasis in original).

88 For Phillimore's working definition of state, see Commentaries upon International Law (Johnson 1854) vol 1, 93-94.

89 Ibid.

90 Ibid, 96-97.

91 Ibid.

92 Phillimore, Commentaries (1855) vol 2, 97.

93 Surveyed at ibid, 97-100. 
the thing may dictate, not only to the principles of general International Law, but to the particular provision of the European Code'. ${ }^{94}$ For Phillimore, then, the question of non-European states is germane to the nature of the state, evidenced by European interactions, rather than modes or problems of recognition. Where Phillimore seems to grapple briefly with a new (kind of) entity, the relevant meaning of recognition is simply that the new entity recognises the law of nations itself; that old states act as guardians of entry into the new order, the price of which is manifest adherence to the law of nations (at least in part).

Like Phillimore, Twiss does not regard the interaction between Christian and non-Christian powers as having a clear bearing on recognition as a concept, and he similarly examines the Ottoman Empire in his catalogue of different states (albeit in much more detail than Phillimore). Twiss's 1861 edition contains comprehensive chapters on the 'national state systems of Christendom' and the international legal relations between Christendom and the 'Mahommedan World'. ${ }^{95}$ Twiss reads the Treaty of Paris as evidencing the Ottoman Empire having 'acquiesced in the declaration of its admission into the European Family of Nations', and given its general move towards European diplomatic customs it, 'for all practical purposes' seems to have 'adopted the Common Law of Europe'. 96 Given the differences in 'manners and institutions', however, treaty relations 'will probably continue to be extremely anomalous'. 97 After examining those relations, Twiss asserts that Christian principalities within the Ottoman Empire are of a different character both 'politically and internationally' because they retain some degrees of 'National and administrative independence' and various liberties. ${ }^{98}$ But rather than clarify the exact position of these bodies within international society (or any implications for his concept of recognition), Twiss devotes the remainder of that chapter to the Ottoman Empire's internal constitutional arrangements, ${ }^{99}$ before turning to general sources and rights of international law.

\section{Hall and the 'traditional' concept}

William Edward Hall's (1835-94) landmark treatise International Law (1880), published after the unification of Germany and Italy and the establishment of the Third French Republic, gives the clearest general expression of the concept of recognition, and perhaps the most influential and frequently cited formulation. ${ }^{100}$ Hall's account of recognition reflects a modern conception of representative nation-states, and

\footnotetext{
94 Ibid, 101.

95 Twiss, Law of Nations, $45 \mathrm{ff}$.

96 Ibid, 84-85.

97 Ibid, 85-86.

98 Ibid, 94, 97.

99 See ibid, 86-109.

100 Holland called the treatise 'unquestionably the best book upon the subject [of international law] in the English language' and free of the 'rhetorical vagueness' of other works: TE Holland, 'In Memoriam WE Hall' (1895) 11 LQR 113. Lauterpacht also praised the work as 'perhaps the most valuable contribution to the subject by any text-book writer': see H Lauterpacht, 'Recognition of States in International Law' (1944) 53 Yale Law Journal 385, 455-56, n 179.
} 
crystallises the end-point of the first strand of British concepts of recognition as grounded in European-style state formation and diplomatic engagements.

Hall presents an image of the permanent state, a representative and changeable government, with an emphasis on the continuity and clarity of state obligations at international law separate from its internal political systems or changes. Hall's state is neither described in terms of the idealised expectations of the European community nor justified through particular forms of legitimacy or justice, but is simply presented as a corporate personality, now ubiquitous in Europe. Hall uses the language of 'international persons' and defines this as entities that bear, in Bodin's phrase, the 'marks of a state': exclusive control over persons and things within its territory, regulation of external conduct independent of the will of any other community and in conformity with international law, and giving other international persons 'reason to expect' it will exist permanently and sufficiently to 'render it a person in law'. ${ }^{101}$ With a solidified distinction between state identity and government type, international law now looks solely to legal obligations and duties and pays no heed to internal changes in governments or constitutional forms, both of which are agents for the expression of community will that may be superseded at that community's pleasure. ${ }^{102}$

Hall first considers recognition within his introductory chapter as a consequential problem of imperfections in international personality, with those imperfections most clearly apparent in cases of secession and intervention. Communities with 'imperfect' marks of states, such as a flaw in complete independence (the restraints of confederation or holding protectorate status ${ }^{103}$ ) may still be 'admitted to the privilege of being subject to international law, in so far as they are capable of being brought within the scope of its operation'. ${ }^{104}$ Shifting towards the language of perfection/imperfection reflects the normality of states and the ways in which national political communities have gradually coalesced into nation-states. But this shift also suggests some acknowledgement of the variety of ways in which nationstates may be (partly) dependent on other powers, and hence in some way imperfect. Hall's examination of recognition is very much rooted in European secession questions. Belligerent secessions are read through the lens of independent statehood. Secessionist entities hold 'a more complete momentary independence' than confederate or protectorate states, and the uncertainty is not about the extent of imperfection but rather the time for which independence can be maintained. Because belligerent communities are not yet persons, they do not have rights under international law and cannot demand recognition. A third state, however, may recognise them if its interests are affected by the ongoing hostilities, as 'a reasonable measure of self-protection'. 105 Despite this focus, Hall's work largely dispenses with the array of illustrative examples seen in earlier texts. These formerly novel legal quandaries are now widely known, and their difficulties have coalesced into a more solid set of legal principles.

101 WE Hall, International Law (Clarendon Press 1880) 16.

102 Ibid, 17.

103 Discussed in ibid, 19-25.

104 Ibid, 19.

105 Ibid, 28. 
Hall conceptualises recognition as a right contingent on the marks of a state: ' $[t]$ heoretically, a politically organised community enters of right ... into the family of states and must be treated in accordance with law, so soon as it is able to show that it possesses the marks of a state'. ${ }^{106}$ Nonetheless, 'commencement' of statehood begins only with recognition evidenced by the exchange of ambassadors, the conclusion of treaties, and so forth. Current states have no right to withhold recognition, but each is 'allowed to judge' for itself if a community possesses all the necessary marks, and whether it is 'likely to live'. ${ }^{107}$ Hall's exploration of the concept fixates on what he calls the 'general' cause of a new state-secessionist entities coming 'into existence by breaking off from an actually existing state' 108 _ and the rights and duties of third powers. This kind of change is treated with an air of normalcy. Departing from earlier views, Hall proposes a new legal equivalency between the rights of parent states and third powers. Recognition by either does not give the 'gift of independence' but only acknowledges the existence of a claim to independence. This acknowledgement is a question of policy, and prudential concerns are paramount for all parties. 109

Despite the importance of prudence and policy, Hall still asserts that 'true principles' of recognition exist: they are illustrated by British and United States practice in recognition of the South American republics, particularly the statements of Mackintosh and Canning which are endorsed and discussed in detail. ${ }^{110}$ In Hall's reading, that practice supports the general principle that definitive independence is not established and recognition not legitimate if a 'substantial struggle' is ongoing. 111 Where the mother state's struggle to retain control is 'so inadequate' that it provides no reasonable grounds for supposing that the mother state might actually regain control, that resistance 'is not enough to keep alive the rights of the state [or] prevent foreign countries from falling under an obligation to recognise as a state the community claiming to have become one'. 112 Hall concludes his thoughts on recognition, and turns back to the central concern of his text - rights and obligations under international law-examining these in relation to new states. ${ }^{113}$

Hall's treatment of recognition reflects some settling and stability of the concept. He moves beyond the longer descriptive catalogues in Phillimore and Twiss to present relatively clear conceptual content based on now-generalised state practice, fixed on the problems of closest relevance to European powers: secessions. But Hall also makes a significant innovation beyond Phillimore and Twiss in acknowledging two new problems for recognition. These are dubbed as 'rare instances' and given brief mentions, but represent an important development. The first instance involves a state 'artificially formed ... upon territory not previously belonging to a civilised power' with the example of the company-established colony of Liberia noted but not

106 Ibid, 73.

107 Ibid.

108 Ibid, 73-74.

109 Discussed in ibid, 31-34, arguing that current texts are 'somewhat loose': Klüber's view on legitimism is always 'open to contestation' and Wheaton's is 'vague'.

110 Ibid, 76-77.

111 Ibid, $75-78$.

112 Ibid.

113 Ibid, 78. 
examined. The second is where 'a state is brought by increasing civilisation within the realm of law', for which no specific example is given. ${ }^{114}$ Hall does not return to either of these 'rare' instances, and while he does examine the admission of Turkey into the European system earlier in the work, ${ }^{115}$ this is briefly explained as occurring only on the basis of incontrovertible acceptance of European international law. He dispenses very quickly with the more problematic and philosophical quandaries of the nature of non-European powers and their attempts to join the society of nations, even as challenges to these ideas from communities in Africa, the Middle East and Asia are apparent. Similarly, he shies from Klüber's interest in the difficulties of legitimacy and revolution, in favour of looking to solid state policy and practice to ground a clear statement of the principles underlying the concept of recognition. But despite the brevity of this treatment, Hall moves beyond Phillimore and Twiss to acknowledge that changes to international society through colonial states and the possibility of 'increasing civilisation' leading to a demand for admission present discrete problems not, contra Phillimore and Twiss, for the idea of the state, but for recognition as a concept itself. As the next sections demonstrate, in the late nineteenth century the incidents treated as 'rare' by Hall have, to other jurists, been seen as far more pressing for thinking on recognition.

Within the first strand of its development, the concept of recognition is articulated in a 'traditional' form. It focuses on immediate factual propositions about whether or not an entity is independent, what role treaty or diplomatic relations have, and fixates on problems of central relevance to European powers. To return to the theses of conceptual history, there is not yet any real temporal orientation for the concept within broader philosophical, historical or teleological narratives (about, say, the development of communities), nor does it fit any particular ideological or political projects. Recognition concepts collect and distil European diplomatic practice, and, while the modern nation-state is a focus by 1880, the European polity and its forms of diplomatic interaction are not yet explicitly presented as the ideal to which others must adhere. Because the central problem is how to deal with new states born out of the ribs of known and recognised European states, recognition is not seen as a particularly difficult theoretical problem, but rather only a question of which acts of recognition are lawful and supported by facts of political control. While the Christian/nonChristian and European/non-European dichotomies find some brief acknowledgement, these texts largely insulate the concept of recognition from those developments. The next two strands of conceptual change will, however, come to fixate on precisely this new reality, and in doing so move the concept of recognition towards longer horizons, wider audiences, and particular ideological and political projects.

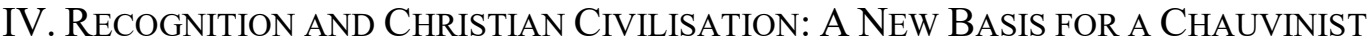 LAW OF NATIONS IN LORIMER, 1873-85}

With the Ottoman Empire's formal admission into the European state system in 1856, civilisation and progress - read as Europeanness and Christianity - slowly emerged in new conceptualisations of many ideas in international law, and by the 1870 s were

114 Ibid, 73.

115 Ibid, 35 . 
central to the new international legal project. While the concordance between law of nations and natural law writings among seventeenth and eighteenth century English and British jurists sits, as in the rest of Europe, as a foundation for modern forms of international law thinking that emerge in the nineteenth century, ${ }^{116}$ the focus on intraEuropean (and intra-Christian) disputes meant that Christianity as the basis for the law of nations did not require any in-depth analysis or defence in the earlier nineteenthcentury texts examined above. ${ }^{117}$ With new encounters and the co-option of nonChristian powers representing non-European civilisation into the European family of nations, jurists began to reassert the purportedly Christian basis of international law and its mission of advancing European civilisation through law. The works of British jurists reflect the development of this trend towards resurgent religious elements in international law. Responding to the recent, strong tradition of positivist criticisms emerging from Bentham to Austin to Pollock, who contended that natural law lacked any real connection to law and gave religion a merely historical or marginal role in law's content, ${ }^{118}$ some British jurists - chief among them James Lorimer-mixed elements of natural and positive law in their attempts to grapple with problems of international law. ${ }^{119}$

The link between Christianity, progress and international law was reinforced by the establishment of the Institut de Droit International in 1873. The Institut's express objectives were to act as the 'legal conscience of the civilized world', in Bluntschli's memorable phrase. In Koskenniemi's view, international law became simultaneously bound to the specific histories of nations and peoples while also holding a universal essence: 'national laws were but aspects or stages of the universal development of human society', and the Institut's task was to bring jurists to argue, agree on and write the law emerging from these nations. ${ }^{120}$ But another important goal was to spread this law over the world. Within two years of its establishment, in 1875, the Institut established a commission of its members to consider how international law might apply to the 'nations of the east', asking 'whether there is any such radical difference between the creeds and notions of Oriental people compared with the Christian people of Europe, as to render it impossible for the Nations of Europe to admit the Nations of the East into the general community of International Law?' 121 This kind of project rested on the prevailing European belief that European states would act for the optimistic ideals of progress and civilisation.

116 See J Tyrrell, A Brief Disquisition of the Law of Nature (Baldwin 1692); R Cumberland, A Treatise of the Laws of Nature (Phillips 1726); Mackintosh, Discourse.

117 See, eg, Hall, International Law, 34.

118 See Bentham, 'Principles of International Law'; J Austin, The Province of Jurisprudence Determined (Murray 1832); F Pollock, Essays in Jurisprudence and Ethics (Macmillan 1882) ch 1 (on Holland and Lorimer). See also JE Noyes, 'Christianity and Theories of International Law in Nineteenth Century Britain' in MW Janis and CM Evans (eds), Religion and International Law (Martinus Nijhoff 1999) 235, 237-38.

119 Manning, Commentaries on the Law of Nations, 67; Phillimore, Commentaries (1854) vol 1, v.

120 M Koskenniemi, The Gentle Civilizer of Nations: The Rise and Fall of International Law, 1870 1960 (CUP 2001) 42-47.

$121 \mathrm{~T}$ Twiss, 'Applicability of the European Law of Nations to African Slave States' (1876) 1 Law Magazine and Review 409, 409. 
These aspects soon find their way into theories of recognition. The differentiation between the recognised and the unrecognised would come to be on the basis of civilisation. ${ }^{122} \mathrm{New}$ articulations of the concept of recognition began to incorporate civilisational and Christian elements to respond to the 'problem' of the entrance of non-European political communities into the society of nations. International lawyers, united by a civilising mission, were no longer solely focused on intra-European norms of conduct. Newcomers needed to defer to and be subordinated to law-both international and domestic - in a European mode. Recognition's question become one of finding Europeanness in different forms of political life and culture. With the reliance on relatively vague and contestable ideas like 'civilisation', 'Europeanness' and 'Christianity' that held immense rhetorical, ideological and teleological content, international law texts of the late nineteenth century begin to articulate more theoretical, historical-progressive framings that reflect international law's new global civilising mission of spreading European ideals across the world.

Several British jurists were at the forefront of this project, and prominent among them-particularly regarding the concept of recognition-was Lorimer. In Schmitt's view, Lorimer contributed greatly to the formalisation of thinking about recognition and its criteria. 123 While Schmitt's own resentments towards Britain raise questions about parts of his polemic, this story is central to many later (and lesscontroversial) works. ${ }^{124}$ Lorimer's work most clearly connects the concept of recognition to the new project of progress in a Christian guise. He presents the first thoroughly theoretical account of recognition, placing it as the foundational concept of international law as a systemic whole. Ranging well beyond a fact-centred analysis seen in the diplomatic catalogues, Lorimer's concept of recognition incorporates ideas of historical progress and a heavily racialised account of the constituent parts of international society. Whereas differences between earlier jurists on recognition might be seen as driven more by their individual emphases and readings of events, Lorimer introduces a radically different account of the nature, importance and centrality of the concept of recognition in international legal thought. It is also grounded much more in political projects of the day. His thought then represents, in the language of conceptual history, an important move towards a concept of recognition with a 'progressive' slant. Recognition is fitted into a longer horizon of philosophical, historical and teleological development, now capable of articulating political and ideological projects - it is the explicit means and measure for the promotion of Christianised, European international law for the good of benighted non-European peoples; at least, those that Lorimer thinks can be saved.

\section{A. Lorimer's early works}

122 See, eg, G Simpson, Great Powers and Outlaw States: Unequal Sovereigns in the International Legal Order (CUP 2004) 232-35.

123 Schmitt, Nomos of the Earth, 214 and 228.

124 See, eg, A Anghie, Imperialism, Sovereignty and the Making of International Law (CUP 2005) ch 2; J Pitts, 'Boundaries of Victorian International Law' in D Bell (ed), Victorian Visions of Global Order: Empire and International Relations in Nineteenth-Century Political Thought (CUP 2007) 67; C Sylvest, “"Our Passion for Legality": International Law and Imperialism in Late Nineteenth-Century Britain’ (2008) 34 Review of International Studies 403. 
Despite laudatory death notices in the $R G D I P$, and scattered later acknowledgments of his importance, ${ }^{125}$ Lorimer was for much of the last century a largely forgotten figure. Interest in his work has only recently been revived. ${ }^{126}$ Lorimer was undoubtedly the most overtly theoretical or 'speculative' British international lawyer of the era. ${ }^{127}$ As a Scottish jurist teaching within a hybrid common and civil law jurisdiction, he was far more closely aligned with European thinking. With an eclectic education in chemistry, zoology and philosophy partly garnered from frequent visits to continental Europe, Lorimer was heavily influenced by the idealist philosophy of the German Friedrich Dahlmann 128 and the Scot Sir William Hamilton, who had encouraged German idealism among many Scottish academics. ${ }^{129}$ His closest friends were several other original founders of the Institut de Droit International. ${ }^{130} \mathrm{He}$ was sternly critical of 'chroniclers' like Wheaton. Practical recordings of policies distracted from Lorimer's real interest in absolute standards and universal laws derivable from reason, which he urged covered international law and made it a system discoverable-like the laws of chemistry or zoology - through scientific examination. These methods of scientific classification of natural laws, and application to legal and political questions, characterise his work.

Lorimer's early works, appearing at the end of his unsuccessful career at the Bar in the early years of his professorship, laid out aristocratic criticisms of representative democracy that presage his later views on political communities and recognition. ${ }^{131}$ Arguing in particular against JS Mill's far more influential views on representation, Lorimer defended 'relative or proportional equality': an essentially aristocratic, anti-egalitarian perspective based in Aristotle's political philosophy. In 1867, Lorimer wrote that 'Human inequality is a fact of nature which society exhibits. Therefore: Our representative system must accept and conform itself to the fact of human inequality as socially exhibited'. ${ }^{132}$ Representative equality cannot be absolute or accorded regardless of 'status' but must be proportionate to the 'positions and

125 See, eg, AP Higgins, 'La Contribution de Quatre Grands Jurists Britannique Au Droit International (Lorimer, Westlake, Hall and Holland)' (1932) 40 Recueil des Cours 1; AH Campbell, 'James Lorimer: A Natural Lawyer of the Nineteenth Century' (1953) 39 Transactions of the Grotius Society 211.

126 See contributions to the symposium 'The European Tradition in International Law: James Lorimer' (2016) 27 EJIL 409, and esp G Simpson, 'James Lorimer and the Character of Sovereigns: The Institutes as a $21^{\text {st }}$ Century Treatise' (2016) 27 EJIL 431.

127 See Campbell, 'James Lorimer', 229.

128 For Lorimer's own recollections on Dahlmann's influence, see J Lorimer, Studies National and International, Being Occasional Lectures Delivered in the University of Edinburgh, 1864-1889 (Green 1890) xii, 53.

129 Noyes, 'Christianity and Theories of International Law', 247.

130 See Lorimer, Studies, ix-xix (by Robert Flint and Gustave Rolin-Jaequemyns); AP Higgins, 'James Lorimer (1818-1890)' (1933) 45 Juridical Review 239; Campbell, 'James Lorimer'; Simpson, ‘James Lorimer and the Character of Sovereigns'.

131 J Lorimer, Political Progress Not Necessarily Democratic, or Relative Equality the True Foundation of Liberty (William and Norgate 1857); Equal Representation (Stanford 1859); 'Application of the Principle of Relative or Proportional Equality to International Organisation' (1867) 24 Transactions of the Royal Society of Edinburgh 557; Constitutionalism of the Future, or Parliament the Mirror of the Nation (2nd edn, Longmans, Green, Reader and Dyer 1867); 'Mill on Representative Government' (1867) 35 Edinburgh Review 534.

132 Lorimer, Constitutionalism of the Future, 29. 
qualities' of those represented; their 'real' value. 133 By 1872, Lorimer had incorporated these positions into his first treatise on natural law, The Institutes of Law, which grounded his view of positive law as a clarification and expression of a community's rational will. ${ }^{134}$ The role for scientific jurisprudence is to study that will, which will ultimately reveal the 'real value' of a political community.

From the 1870s onwards, Lorimer begins to incorporate these ideas of relative inequality and the 'real value' of political communities into his early articulations of a concept of recognition. ${ }^{135}$ These writings are revealing because they focus much more closely on the events of the day than his more speculative treatise. Lorimer's January 1876 lecture, 'Of the Denationalisation of Constantinople' first articulates his view that the pressing problems of international law stemmed from errors in the concept of recognition, namely the inability of the current concept to grapple with the reality of inequality he saw as evident in nature. Considering the 'Eastern Question' (the declining authority of the Ottoman Empire and Russian expansionism in the Balkans in the $1870 \mathrm{~s}^{136}$ ) Lorimer castigated the Great Powers' decision in the Treaty of Paris to take 'refuge in a fiction' by recognising the 'phantom State' of the Sublime Porte:

Incapable of transcending the concept of nationality, and sensible of their inadequacy of that conception when brought to bear on cosmopolitan interests, the Western powers took refuge in a fiction ... In the keeping of a phantom State, which was no longer subject to the changes and chances of mortality, it was hoped that Constantinople had been placed finally beyond the reach of mortal ambition. The Sublime Porte was accordingly admitted by acclamation into the family of European nations, and the Treaty of Paris pronounced him to be entitled to the rights and responsible for the duties which the laws of nations imposes on civilised States. Safe within the barrier of red-tape drawn around him by the Treaty, his independence was guaranteed to him by the doctrine of recognition, the Alpha and Omega of international law! ${ }^{137}$

This vivid and strongly polemical reaction shows Lorimer held recognition to be both the problem and solution to the Eastern Question. '[A]s expounded by nature and by history' recognition is not absolute but instead conditional on a real 'autonomous existence', and 'before nature and history red-tape is powerless and treaties must bow'. ${ }^{138}$ The Great Powers' error here was to apply an 'absolute' doctrine to ignore the 'corpse' of the Ottoman Empire that lacked what Lorimer saw at this point as the first condition of recognition; 'autonomous existence'. ${ }^{139}$ Lorimer's answer to the Eastern Question was the denationalisation of Constantinople, which would have then seemed an ambitious scheme for an international government and

133 Ibid, $22 \mathrm{ff}$.

134 James Lorimer, The Institutes of Law: A Treatise of the Principles of Jurisprudence as Determined by Nature (Clark 1872) bk 3.

135 James Lorimer, Of the Denationalisation of Constantinople and Its Devotion to International Purposes (Edmonston and Dougal 1876). See also James Lorimer, An Inaugural Lecture on the Law of Nature and Nations (Clark 1863).

136 See, eg, AL Macfie, The Eastern Question 1774-1923 (Taylor \& Francis 2014). Among other British treatments at the time, see TE Holland, The European Concert in the Eastern Question (Clarendon Press 1885).

137 Lorimer, Denationalisation of Constantinople, 7.

138 Ibid, 7-8.

139 Ibid, 8. 
joint-occupation by European powers. This included a plan for joint colonial administration of the presently settled Turks that reflected Lorimer's affinity for civilising missions: 'I would make of the Turk all that a civilised man can ever make of a barbarian — namely, a pupil ... I would give up the farce of pretending that he was sui juris'. 140

By the late $1870 \mathrm{~s}$, relative equality and real value were presented in general, systematic terms. Lorimer's 1878 'Prolegomena to a Reasoned System of International Law' applied Aristotle's ideas on relative equality to the doctrine of recognition. This combination would be 'fruitful' and 'indicates the theoretical solutions of many problems which have hitherto been regarded as insoluble', namely that looking to the 'quality' of state existence would allow smaller, protectorate and semi-barbarous states to gradually develop into full persons and thus practically realise the desirable spread of the law of nations across the world. ${ }^{141}$ With these foundations laid, Lorimer's Institutes of the Law of Nations presented his grand vision for 'assisting' in 'solving' the seemingly insoluble problems of the law of nations by placing the system on its correct foundation of a true doctrine of recognition.

\section{B. Recognition in Lorimer: race and progress}

Lorimer defines international law as the 'law of nature realised in the relations of separate nations'. It aims at the freedom of each nation, achieved by the reciprocal assertion and recognition of the 'real powers' of those nations. ${ }^{142}$ After a lengthy and somewhat polemical discussion of the works of 'elder jurists', ${ }^{143}$ Lorimer concludes that these thinkers placed too much emphasis on 'false or partial' analogies between states and human individuals. ${ }^{144}$ In contrast to both their works and those of contemporaries like Twiss (who placed national independence at the basis of international law), Lorimer grounds international law on interdependence and 'ethnical groups': 'it is only when, by the action of historical and geographical factors, [ethnical groups] have crystallised into political bodies, that they come within the scope of a treatise on the law of nations'. ${ }^{145}$ This emphasis on ethnical groups rather than sovereigns or states is central to Lorimer's methodology. Whereas in the Institutes of Law Lorimer had based his view of autonomy on human anthropology, ${ }^{146}$ in the Institutes of the Law of Nations he moves to 'jural ethnology', his own specifically legal formulation of the then-fashionable 'science of races'. ${ }^{147} \mathrm{He}$ took ethnology as the science most likely to greatly influence international politics and jurisprudence because it had 'insensibly modified the old historical and geographical conceptions of nationality', which in turn would ground new sciences of 'comparative ethics, politics,

140 Ibid, 19.

141 Lorimer, Studies, 156.

142 James Lorimer, The Institutes of the Law of Nations: A Treatise of the Jural Relations of Separate Political Communities (Blackwood 1883) vol 1, 3-4.

143 See ibid, bk 1 ch 5.

144 Ibid, 80.

145 Ibid, 101.

146 Lorimer, Institutes of Law, bk $1 \mathrm{ch} 4$.

147 Lorimer, Institutes of the Law of Nations, 93. 
and jurisprudence' that would greatly develop the positive law of nations. ${ }^{148}$ Ethnology would be the science to discover the 'facts' upon which jurists could base their assessment of whether non-European political communities could attain recognition.

Because Lorimer saw differences of 'ethnical will' as the permanent factor causing political differences, ${ }^{149}$ the ultimate 'international question' was whether 'we are entitled to confine recognition to those branches of alien races which consent to separate themselves from the rest, and, ostensibly or professedly, to accept our political conceptions'. ${ }^{150}$ With this stark conceptual innovation, Lorimer overtly gives recognition an ideological and political purpose. It is a concept that should be used to exclude communities that do not accept or demonstrate European-style government. And Lorimer assigns to this task directly to the jurist. Jurists must identify the ethical differences produced by these ethnical differences and thereby distinguish the 'universal ethical' from the 'local, even if permanent, ethnical elements which enter into every political and international problem'. ${ }^{151}$ Clarifying this absolute standardto be found in the 'laws of our common nature' but at present unrealised but realisable through ethnology) — would then allow jurists to evaluate whether a mass of 'ethnical facts' will entitle a particular group to international recognition. ${ }^{152}$

With this new project stated, Lorimer turns to the concept of recognition itself, beginning with the idea with which he has since become most closely associated; 153 the concentric zones of humanity:

As a political phenomenon, humanity, in its present condition, divides itself into three concentric zones or spheres - that of civilised humanity, that of barbarous humanity, and that of savage humanity. To these, whether arising from peculiarities of race or from various stages of development in the same race, belong, of right, at the hands of civilised nations, three stages of recognition ... ${ }^{154}$

Relative equality exists between the entities both within a circle and across the different circles; communities are 'no more equal to each other, in the absolute sense, than their citizens are equal. They differ in powers, and consequently in rights; and the recognition which they are entitled to claim from each other is proportioned to their powers and rights'. 155

The first sphere of plenary recognition corresponds to civilised humanity: all European states, their colonial dependencies provided they are 'peopled by persons of European birth or descent', and the states of the Americas that have gained independence. Lorimer thus maintains, as the general core, roughly the same intraEuropean image of recognition that can be seen in Phillimore, Twiss and Hall. Attaining this highest stage of recognition involves a formal declaration, preceded by

148 Ibid.

149 Ibid, 97.

150 Ibid, 98 .

151 Ibid, 99.

152 Ibid, 98-99.

153 See Simpson, 'Lorimer: The Character of Sovereigns'.

154 Lorimer, Institutes of the Law of Nations, 101.

155 Ibid, 103. 
an 'inductive process' in which an entity satisfies itself that another 'phenomenally presented to it, possess[es] a separate political existence' by showing it can perform the duties of international existence and is thus entitled to the rights that 'centre' in that existence. ${ }^{156}$ But, departing from those earlier views, Lorimer strongly rejects this as an act of 'courtesy' or 'comity' that can be withheld: asserting recognition is a right and accepting it is a duty. 157

Lorimer's significant conceptual innovation lies in his introduction of the second and third spheres to create an image of concentric circles of recognition. Partial political recognition is extended to the barbarous civilisations: the Ottomans and the 'old historical States of Asia which have not become European dependencies', including Persia, China, Siam and Japan. '[N]atural, or mere human' recognition' extends to the 'residue of mankind' divisible into progressive and non-progressive races; Lorimer presumably means, but does not explicitly name, the tribal communities of Africa, the Americas, Oceania and Asia. While the positive law of nations need not be applied to savages or barbarians, the tasks for jurists is to scientifically determine exactly which non-European communities come into international law, and to what partial extent. ${ }^{158}$ Turkey's recognition was a premature 'bitter experience', 159 though Japan, in another 'twenty years' might progress sufficiently to raise the question whether it is 'entitled' to plenary political recognition. 160

Position and progress through the spheres depends on the assessment of states in the 'superior' spheres. ${ }^{161}$ Jurists from these states are tasked with making this assessment by applying the ideas of rational will and jural capacity to the putative state. 162 This process of assessment will furnish 'maxims' of recognition which prevents states from either 'twist[ing]' or sitting as the 'absolute judges' of both facts and law. ${ }^{163}$ Distilling the thus far 'vague and often contradictory' juristic efforts to conceptualise recognition, 164 Lorimer states that recognition has two general requirements:

In order to be entitled to recognition, a State must presumably possess;

(a) The will to reciprocate the recognition which it demands.

(b) The power to reciprocate the recognition which it demands. ${ }^{165}$

156 Ibid, 104.

157 Ibid, 104-105.

158 Ibid, 102.

159 Ibid, $102-103$.

160 Ibid, 103.

161 See ibid, 105-109.

162 Ibid, vii-viii.

163 Ibid, 108.

164 Ibid. Although Lorimer does not explicitly attribute these 'vague efforts' to any specific writers, in later discussions he demonstrates a closely familiarity with the relatively recent works of Klüber, Martens, Wheaton, Phillimore and Bluntschli, among others.

165 Ibid, 109. 
Recognition focuses on an assessment of the presumption that a community claiming recognition has the will and the power to reciprocate that recognition. The newcomer must present to the states from which it claims recognition 'a reasonable presumption that it is able, as well as willing, to perform the duties incident to international existence'. 166 Whether the presumption is reasonable, and whether the newcomer is willing and able to reciprocate recognition depends on whether it possesses the conditions required for 'jural capacity'. Political communities based on 'intolerant' creeds are excluded from this presumption: religions that do not allow divine revelation to be tempered by secular knowledge (Judaism, Mahometanism and perhaps some forms of dogmatic Catholicism) and political creeds that place singular faith in either particular laws or law-making organs (absolutist monarchies, aggressive empires, republics based on the infallibility of 'the people', nihilists). ${ }^{167}$ Drawing on his earlier domestic articulation in the Institutes of Law, Lorimer defines 'jural capacity' as the presence in the subject of a will that 'partakes of such a measure of relative freedom as will enable it to exhibit itself within the sphere which the existence of the subject assigns to it as real and ultimate power'. ${ }^{168}$ This rather convoluted formulation applies to states. A state holds jural capacity and reciprocating power (and thus entitlement to recognition) where it "possesses [a] will which, up to the limits imposed upon it by the other conditions of its own existence, it can freely realise in action' evidenced by its ability to consent or contract, 'just as a citizen in a corresponding position is entitled to the suffrage, or a person is entitled to buy, and to sell, and to marry'. 169

Because the jural capacities of communities vary widely based on how well they represent the rational will of their peoples, the major task for jurists is to ascertain the relative value of different states throughout the world. Lorimer outlines in detail the kinds of considerations he takes to be relevant for this evaluation-territory, population size, material wealth, intellectual and moral capacities of citizens, the degree of 'separateness' (not, explicitly, independence) ${ }^{170}$ from other communities, internal freedom demonstrated by autonomy and autarchy - all ultimately indicating the presence or absence of a degree of rational will and a form of government capable of expressing the relative freedom of the state. ${ }^{171}$ Lorimer precludes barbarians, savages and undeveloped races from expressing any rational will because they are child-like, imbecilic, in pupillage to superior races, or criminals. ${ }^{172}$ But of those that have some degree of rational will and are capable of expressing relative freedom, their relative value lies in the influence they can 'exert in determining the direction of

166 Ibid, 133.

167 See ibid, 113-33.

168 Ibid, 135, citing James Lorimer, The Institutes of Law: A Treatise of the Principles of Jurisprudence as Determined by Nature (2nd edn, Blackwood 1880) 415, 426, 427.

169 Lorimer, Institutes of the Law of Nations, 135.

170 Ibid, 140: 'As the claim to recognition is a logical abandonment of independence, it is a logical profession of separate political life'.

171 See ibid, 136-56.

172 Ibid, 157-61. The 'criminality' of the Barbary States explains why they were never properly recognised by European states despite extensive treaty arrangements, and France's conquest of Algeria did not violate international law because it was justified as 'an act of discipline ... in the absence of [international] police': at 161. 
international action'. ${ }^{173}$ By this Lorimer does not mean simply power over other states, but rather whether a particular state has a form of government best suited to its historical and worldly situation: 174 'the most perfect government for a particular State will be that which places it, as it is, in the most perfect relation with the States by which it is recognised, as they are.' 175 The tests to be applied to governments are similar to those applied to forms of the state:

To what extent do they enable the State claiming recognition, by concentrating its whole rational will, to contract as a single individual? To what extent do they enable the State claiming recognition to satisfy the States from which recognition is claimed, that its apparent is coincident with its real rational will? ${ }^{176}$

Lorimer's ranking the governmental forms that best answer these questions accords with his preference for relative equality: constitutional monarchies that embrace the whole population and rank their citizens 'as relatively or proportionally endowed with rational will'; constitutional republics resting on the rational will of the community; constitutional states that only partly embrace the rational will; non-constitutional states where rational will 'finds expression' only in the society's 'organic structure'; and, lastly, pseudo-despotic or pseudo-democratic states. ${ }^{177}$

Having laid out these principles, Lorimer turns finally to their application to the present world. Lorimer concedes that forcing states, particularly the Great Powers, to accept their actual relative rank involves a '[v]ery great difficulty', but insists that the progress of international organisation and the freedom of smaller states depends on it. ${ }^{178}$ As between the Great Powers, the principle of absolute equality should be retained and 'fortunately ... conflicts less flagrantly with fact than when applied to the relations between them and the lesser States'. ${ }^{179}$ As to smaller and new states, an international position reflecting their real value and importance must be assigned, and in the absence of an international legislature, executive and judiciary, this lies with current states. ${ }^{180}$ States can thus progress and retrogress in their relative positions, and retrogression or domestic challenges to its internal authority may lead to the withdrawal of recognition, or extinction altogether. ${ }^{181}$ Partial recognition can be accorded by states in a higher sphere to those in a lower one, with the degree of recognition reflecting a state's progress towards civilised status. An important indicator for Lorimer is municipal law, evaluated by the presence of foreign or consular jurisdiction. While between civilised states the decisions of each others' courts are recognised (absent differences on notions of 'morality, or public policy'), ${ }^{182}$ between civilised and semi-barbarous states recognition does not extend

173 Ibid, 181.

174 See ibid, 189-205.

175 Ibid, 204 (emphasis in original), citing Lorimer, Institutes of Law (2nd edn) 356.

176 Ibid, 207.

177 See ibid, 208-12.

178 Ibid, 212-13.

179 Ibid, 213-14.

180 Ibid.

181 Ibid, 214.

182 Ibid, 216. 
to municipal law, and separate courts are needed to decide questions arising between foreign nationals of 'civilised' states, and between such nationals and the citizens of the semi-barbarous state. ${ }^{183}$ In Lorimer's evaluation, as of 1883, the Ottoman Empire, China and Japan had reached a 'stage of progress' midway between protected and recognised, such that a new descriptor 'conjoined with the term recognition' seemed appropriate. ${ }^{184}$ But the difficulty of generalising a possible adjective was the need for European powers to interfere with their internal government 'so often called for on grounds of humanity', meaning these states are 'constantly relapsing into the position of protected States'. 185

Lorimer concludes his lengthy articulation of the concept of recognition by suggesting that his ideas of relativity and recognition are in fact reflected in the current system of partial recognition. Perhaps surprisingly, given his racial chauvinism and dismissive evaluations of governmental capacity beyond Europe, he offers something close to a lament at European treatment of partially recognised states. Putting aside Turkey's 'technical recognition', which makes it 'anomalous', Lorimer notes that no partially recognised state has been 'permitted to take part in the counsels of civilised nations', notwithstanding that their right to relative recognition is 'incontestable' on the basis of trading connections alone. 186 In particular, he suggests that no 'ground of absolute justice' supports China's exclusion from bringing 'her standing grievances against us [that is, Britain] with reference to the opium trade to the notice of other nations'; a clear reference to the Opium Wars of 1839-60. ${ }^{187}$ Lorimer writes that as every European state receives China's ambassadors, 'why should a seat and a vote, if proportional voting were admitted, be denied to [those ambassadors] in diplomatic gatherings?'; given her status as the 'greatest of all the Asiatic powers', China 'could not have been indifferent' to the Berlin Congress of 1878 and was certainly at least an interested neutral in the British war in Afghanistan in 1879. 188

Lorimer's work significantly expanded the meanings and importance of the concept of recognition. It makes several radical innovations to the traditional concept of recognition depicted in the works of Phillimore, Twiss and Hall. First, he replaces the binary recognised/unrecognised with a three-tiered gradation of (to his mind) clearly divided spheres. This gradated recognition is expanded to cover all political communities, rather than just those with whom European sovereigns have diplomatic relations. Secondly, he introduces a range of new criteria as relevant for recognition: express examinations of ethno-racial characteristics of communities, a focus on the expression of the political will of a community, the will and ability to reciprocate recognition, and a range of impermissible political formations and creeds. Thirdly, Lorimer's concept grants a central task to jurists as the investigators and arbiters of legal principles and factual realities, and the concept itself structures that enquiry entirely. Returning to the guiding hypotheses of conceptual history, Lorimer's view of

183 Ibid, 217.

184 Ibid, 218.

185 Ibid.

186 Ibid.

187 Ibid, 219. On the Opium Wars, see, eg, Ronald Hyam, Britain's Imperial Century, 1815-1914 (2nd edn, Macmillan 1993) 123-33.

188 Lorimer, Institutes of the Law of Nations, 219. 
recognition takes on a clear temporalized, teleological and progressive element in its overarching claim that communities may move through the gradations by political development, and by looking to longer historical trends rather than merely recent intraEuropean secessions and rebellions. It shifts and restricts the community of authoritative interlocutors to jurists alone, but expands their audience to the rest of the world's polities. And it now holds more pronounced ideological and political tones, promoting inclusion and exclusion along ethno-racial lines, seeking to entrench aristocratic understandings of the state and international society, and attempting to give European political elites a language for dealing 'justly' with those non-European polities with whom they are increasingly intertwined.

Lorimer's world is starting to deal with non-European polities more often, in closer and - in some cases - constant, stabilised contact. Overlaying that contact is a Christianised mission of progress that promotes particular forms of life and government. Lorimer's concept of recognition not only makes diversity centrally relevant for its meaning, but categorises and structures differences between polities to create a teleology of progress towards European, Christian aristocratic states. Lorimer's account goes beyond merely cataloguing diplomatic practice. It tasks international lawyers with debating and deciding what kinds of political bodies are capable of recognition at all. For Lorimer, the perceived clash of civilisations and the new diversity of frequently radical government types within Europe make this an urgent task. Lorimer's concessions to partial recognition are a product of increased intercourse with the Ottoman Empire, the Chinese dynasties and Japan: regulating those interactions through law meant some measure of internal competency had to be granted to these states (with notable resistance from nations like Britain, who continued to refuse to recognise Ottoman competency). Lorimer's work on recognition presents the clearest articulation of a new racially-charged Eurocentric basis, appearing just prior to late stage colonialism following the Berlin Conference, and just after the emergence of newly-unified nation-states within Europe - and the ascendancy of that form of political organisation. And while his 'jural ethnology' remains particularly repulsive today, it bears recalling that evolutionary approaches to analysing political communities and their interactions were far from uncommon in British writings at the time. ${ }^{189}$

\section{RECOGNITION AND COLONIALISM: CIVILISATIONAL SUPERIORITY SANITISED IN TWISS, WESTLAKE AND OPPENHEIM, 1885-1914}

Lorimer's concept of recognition rarely gained much acceptance or support among other British jurists, and it is rarely cited favourably by them. Yet many aspects of his concept and worldview are consonant with the next phase of theorising on recognition, which had a more lasting influence. Whereas Lorimer attempted to make sense of how increasing connections between European and non-European powers should affect the principles of international law, writings after 1885-the year of the Berlin Conference - shift towards active projects of colonialism. These writings consolidate a more technical approach to recognition. They combine civilisational and Christianfocused understandings of recognition with ideas of government, effective control and

189 See esp W Bagehot, Physics and Politics (6th edn, Kegan Paul, 1881); HS Maine, VillageCommunities in the East and West Six Lectures Delivered at Oxford (Murray 1895) (delivered in 1871). 
territorial sovereignty that stem from now-dominant European visions of nation-state organisation. With increasing treaty and consular interaction between European states and non-European political communities that were still seen as having very different levels of organisation and civilisation (from 'Asiatic empires' to 'bands of savages') the question of the status of these communities is no longer primarily about diplomatic processes of recognition. The mere signing of treaties or presence of extraterritorial jurisdiction, which would otherwise indicate at least partial satisfaction of the criteria for recognition, are not as important as levels of government, demonstrated 'civilisation' or the ability to guarantee protection of the lives and rights of foreign citizens. Recognition is discussed and understood in the context of other doctrinal questions about territorial sovereignty, treaty connections, and government types with these 'different' civilisations of the East as well as the appropriation of 'uncivilised' regions. The speculative, metaphysical problems for European international law's encounter with other forms of political life found in Lorimer are left to one side in favour of using international law to coordinate and justify colonial projects. By the time Oppenheim inaugurates a new positivist school of international legal thought, placing the state at the centre of international law to the exclusion of all other communities and persons and holding that a state becomes an international person solely through the process of recognition, the civilisational criterion is effectively muted and entrenched into the assumptions about what members of the international community can look like. This third strand of thinking about recognition involves a mixture of civilising mission with more technical and detailed legal analyses that incorporate other legal ideas used in the colonial division, control and expansion of Europe's periphery. Chauvinist ideas of European civilisational superiority found in Lorimer are gradually mainstreamed and sanitised by a veneer of positive law.

\section{A. Twiss's later works}

Following a scandal that resulted in him resigning the Regius Professorship and the office of Queen's Advocate-General and retreating from public life in 1872, Twiss continued to publish on international legal issues. While he did not update the concept of recognition in later editions of his treatise, he did take a more detailed interest in the new changes in civilisation and contacts with Europe's periphery already gestured to in the first edition of his treatise. ${ }^{190}$ These later works examined ideas of territory and sovereignty in the context of European-periphery contacts and colonial projects, and come to reflect his late views on recognition.

Twiss did not share Lorimer's conviction that certain religious 'creeds' rendered polities ineligible for recognition, and took a rather more optimistic, conciliatory view of the interactions between Europe and non-European states. In an 1876 article reporting on the Institut's proceedings on whether the 'radical difference between the creeds and notions of Oriental people' precluded them from admission to the European international legal system, Twiss went as far as stating that, even before 1856, the Ottoman Empire 'from a Christian point of view ... had been already received as a Peer into the European Parliament of States' because Ottoman

190 Twiss, The Law of Nations, chs 3 and 4, on the national state systems of Christendom and the Ottoman Empire, respectively. 
ambassadors were admitted to reside at the courts of two European powers. ${ }^{191}$ Twiss identified a 'growing desire [among] Mussulman Races to place themselves on the same platform of Public Law with the Christian Races of Europe'. ${ }^{192}$ Manifested adherence to that law was central to their legitimate statehood and their capacity for recognition. Specifically, that required Islamic states to renounce the 'creed' of jihad by concluding treaties of amity with European states. 193 While the long history of treaty relations between European and African states on piracy and the slave trade provide early indications of that willingness, as well as the 'recognition' of 'a jus commune gentium in certain matters, applicable equally to African as to European States', Twiss did not yet regard the latter states as fully part of the 'European StateSystem'. 194

But like Lorimer, Twiss saw this eventual recognition as lying with 'progress' - albeit not a speculative or metaphysical idea, but rather a particular focus on the maintenance of and adherence to treaty relations combined with the development of domestic legal institutions in a European mode. Twiss had no reservations in extending the term 'state' to any polity willing to operate under European international legal rules. But the exact position of these states within the European system remained precarious and contingent on abiding by those treaties. Ensuring stability in the successful intermixing of Western and Eastern civilisations was an inevitable, important question of progress to be answered, thought Twiss, by institutional development: 'The problem ... in which all the Christian Nations of Europe have an equal interest is how to graft the political institutions of Western Europe upon the social institutions of the Mahommedan world'. ${ }^{195}$ Admitting that Eastern civilisations might 'overtake' Western ones, Twiss argued that Western races should maintain their permanent 'prestige among the Eastern Races' by ensuring the 'incorrupt administration of justice'. ${ }^{196}$ The context of this exhortation was the establishment of new international tribunals in Egypt which might also serve as models for the progress of local courts. 197

Twiss's writings on African colonial expansion introduced a second way in which he thought progress might occur while simultaneously avoiding the recognition of any 'new' states: by reviving older medieval forms of recognition, applying them to national-commercial entities, and urging the exercise of consular jurisdiction. His 1883 pamphlet, 'An International Protectorate of the Congo River', which pre-dates the Berlin Conference and advocates for European penetration into the Congo by the establishment of a Protectorate rather than a neutral zone, ties recognition to older ideas of personal sovereignty in the context of commercial exchange precisely to avoid the recognition of indigenous polities. ${ }^{198}$ As with Egypt, Twiss saw the need for introducing European laws, but with modifications suited to the conditions of the

191 Twiss, ‘African Slave States', 410.

192 Ibid.

193 Ibid, 410, 413.

194 Ibid, 417. See also at 414-16, 424, 436-37.

195 T Twiss, 'Leibnitz's Memoir upon Egypt' (1883) 8 Law Magazine and Review 237, 257.

196 Ibid, 258 (emphasis in original).

197 Ibid, 258-59.

198 T Twiss, An International Protectorate of the Congo River (Pewtress 1883) 16-17. 
region. 'Europe may feel called upon to engraft the same principles of public law upon the institutions of a sister continent, as may have been found to work well in Europe', but the ideas of sovereignty prevailing among the tribal communities will require 'caution' — and also preclude their recognition as states:

The organisation of the native races on the banks of the Congo is still tribal, and territorial. Sovereignty in the sense in which it has superseded personal Sovereignty in Europe, is still unknown. Personal Sovereignty, however, is recognised by the European traders on the Congo, and each factory hoists the flag of the nation, from which the trader holds himself to be entitled to claim protection, if he should be engaged by a native chief, or by a trader of another European nationality. ${ }^{199}$

For Twiss, these 'local' recognitions of personal sovereignty indicated the existence of an 'element of order' to which European governments ought to give their 'careful consideration' before the 'throng' of traders arrives. ${ }^{200}$ Twiss's solution lay in an International Commission of the Congo River built on recognition of personal sovereignty - albeit in the form of European consuls, not the recognition of indigenous sovereigns. 'Personal Sovereignty, if effectively brought into play, would be an obvious remedy for the state of "wrong and unlaw": namely, each European state would authorise its own Commissioner to exercise consular jurisdiction on the state's behalf over their citizens. ${ }^{201}$ The need for a judge consul - 'an institution of an age, when the theory of territorial Sovereignty had not as yet superseded in Europe that of personal Sovereignty' - arose from the posited impossibility of recognising territorial sovereigns in the Congo region. ${ }^{202}$ Citing precedents of nineteenth-century international conferences granting Greek independence and resolving 'political difficulties in Asia and Northern Africa', and noting that no pre-existing suzerain entity is needed to give validity to this kind of agreement between Christian powers, Twiss concludes this new Congo Protectorate 'would be an International accord worthy indeed of the civilisation of our epoch, and might arrest at once the further growth of any nascent difficulty', that is, of European disagreements or warfare in the Congo. 203 A creatively modified concept of recognition, reverting to old forms of sovereignty, is central to Twiss's proposed solution.

While Twiss's revised and enlarged 1884 treatise does not modify his account of the concept of recognition from its 1861 form, it does include an intriguing new preface that catalogues the major contemporary issues facing a changing system of international law, almost all of which bear on challenges to and expansions in the use of recognition. ${ }^{204}$ A first innovation is the centrality of international congresses for recognition practice. While changes within Western Europe, such as the constitution of

199 Ibid, 17 (emphasis in original).

200 Ibid.

201 Ibid.

202 Ibid; and see at 18 Twiss's analogy with the papal instrument of exequatur which carried implied recognition.

203 Ibid, 19.

204 T Twiss, The Law of Nations Considered as Independent Political Communities: On the Rights and Duties of Nations in Time of Peace (3rd edn, Clarendon Press 1884) ch 2. Twiss only substitutes 'natural independence' for 'absolute independence' in the 1884 edition, likely to avoid the appearance of naturalism. 
the new German Empire and the unification of Italy, did not require recognition through conferences, the partial dismemberment of the Ottoman Empire and the new independence of its Balkan kingdoms needed 'the sanction of a Congress'.205 Secondly, Twiss reads the 'increased willingness ... to adjust ... civil institutions to the general European standard' in the Ottoman Empire and Egypt as an institutional development indicating that these polities had moved closer to inclusion in the system of European public law. ${ }^{206}$ Thirdly, and most substantially, Twiss provides a lengthy consideration of the recognition of 'association' territories in Africa, reflecting his recent interest in the Congo:

Another question in connection with Africa has already assumed a prominent place inter apices juris Gentium [among the subtleties of the law of nations] ... namely the capacity of private associations of a philanthropic character to accept cessions of territory with full rights of dominion from the native chiefs of Africa, so as to acquire for any settlements which they may establish in such ceded territory a Status, which in due course of time will warrant on the part of the nations of Christendom a recognition of such settlements as independent States. ${ }^{207}$

Noting the abundance of cases in the 'far East, where chartered companies have been the pioneers of European civilisation' and have validly acquired 'international status ... [by obtaining] cessions of territory and full rights of dominion from native chiefs', 208 Twiss discusses the establishment and gradual recognition of the independence of Liberia before noting the Congo Question: the problem raised by the Brussels Association's lack of political control over settlements in the Upper Congo beyond 'taking measures to secure that the frontiers of its settlements shall be open freely to the commerce of all the world' and ensuring that any person can settle at its stations with equal rights and privileges on the condition of obeying its laws. ${ }^{209}$ Declining to delve into this Question, Twiss states that several jurists have been 'embarrassed' by their confused and "popular use of the term "Sovereignty" and suggests " "full dominion" would have been more appropriate' in avoiding problems of Roman and Feudal law distinctions between personal and territorial sovereignty. 210 To conclude the preface, Twiss reiterates his emphasis on independence as the signal of the capacity to be recognised, but now relates that requirement to the context of deepening colonial expansion and emphasising autonomy as the marker of independence:

The Republic of France, which is acquiring the rights of Empire in the present day over extensive territories in Western Africa, acknowledges no personal Sovereign. It is the autonomy of a State which is the criterion of its independence, not the circumstance of its being ruled by a Sovereign Prince; and it is a lingering tradition of a past age, which suggests that none but Sovereign Princes or associations chartered by them can found settlements out of Europe, which will be entitled to claim international

205 Ibid, vii.

206 Ibid, viii-ix.

207 Ibid, $x$ (emphasis in original).

208 Ibid, $x$ (emphasis in original).

209 Ibid, xiii-xiv.

210 Ibid, xiv-xv. 
recognition, when they are sufficiently matured to maintain the character and to discharge the duties of independent states. ${ }^{211}$

Liberia and Maryland are examples of this, with the former's recognition achieved not by any European Congress 'but after the example of the United States of America itself by a Catena [chain], so to say, of separate treaties with the leading states of the civilised world'. ${ }^{212}$ Twiss may well have thought his 1861 articulation needed no update even despite these new developments. Indeed, he seems to read them as bolstering his original views that independence and the willingness to observe the rules of the law of nations remain the major precursors to recognition. 213

While Twiss's writings in the early 1880s provide some indications of his creative use of the concept of recognition and his acknowledgement of a swathe of recognition questions raised by colonial expansions, it is his close practical involvement at the Berlin Conference in 1884-85 that provided the spur for later conceptual innovations; albeit innovations made in the writings of others. ${ }^{214}$ While part of the British delegation at the Berlin Conference, Twiss came to be an unofficial legal adviser to the King of Belgium, Leopold II, and reportedly drafted the constitution of the Congo Free State. ${ }^{215}$ Although Twiss was instrumental in the practical work of establishing the Congo Free State, he published only one article on the Berlin Conference, placing it on a similar standing as the Congress of Vienna in its influence on European public law and giving high praise to the work of the Belgians as 'preparing' African populations for the principles of European international law. ${ }^{216}$ Twiss's involvement in the Congo Free State reflects the operationalisation of recognition theories of the time, extending its meaning to include privately-established states and solidifying its centrality for the colonial project. But it is with John Westlake's texts that the concept of recognition is developed further to incorporate these new practical uses.

\section{B. Recognition in Westlake: sanitising Lorimer's worldview}

Westlake's writings reflect the clearest incorporation of post-Berlin Conference colonial projects into the concept of recognition. ${ }^{217}$ Westlake could fairly be called the most influential British jurist of the nineteenth and early twentieth century. $\mathrm{He}$ taught for more than two decades at Cambridge, published several major works, fostered Oppenheim's career, and was lauded at the time of his death and for decades

211 Ibid, $x v-x v i($ emphasis in original).

212 Ibid, xvi.

213 Ibid, xxxix.

214 See esp A Fitzmaurice, Sovereignty, Property and Empire, 1500-2000 (CUP 2014) 276ff.

215 See Sylvest, “'Our Passion for Legality”, 410-15.

216 See T Twiss, 'Le Congrès de Vienne et La Conférence de Berlin' (1885) 17 Revue de droit international et de législation comparée 201, esp at 216-17.

217 On Westlake and the Berlin Conference, see esp Matthew Craven, 'The Invention of a Tradition: Westlake, the Berlin Conference and the Historicisation of International Law' in L Nuzzo and M Vec (eds), Constructing International Law: The Birth of a Discipline (Vittorio Klostermann 2012) 363. 
to come as a highly influential scholar. ${ }^{218} \mathrm{He}$ was also a contemporary and close friend of Lorimer. They were both founding members of the Institut de Droit International, and kept up a lengthy correspondence. Westlake is thanked for his comments on the manuscript of Lorimer's 1883 treatise, and received an honorary LLD from Lorimer's University of Edinburgh. While they held very different approaches to international law-Westlake took up a historical-positivist approach along the lines of Henry Maine 219 in contrast to Lorimer's speculative naturalismthey were both familiar with continental thought. 220

Westlake's inaugural lecture in 1888 outlined a practical vision of international law which nonetheless incorporated many elements reminiscent of Lorimer's thought. Like Lorimer, Westlake divides the subjects of international law into sovereign states, semi-sovereign states, and 'half-civilized or uncivilized races'. The latter 'uncivilized or half-civilized races' lie outside the system of states, and must be counted in the 'several degrees in which they approach to having regular governments, ... there would then be completed what might be called a Domesday Book of the world'.221 Westlake also tempered his focus on positive law with a more continental idea of 'jural right'. Drawing an analogy with Bentham's view that 'principles of legislation' may guide the reform of national laws, Westlake saw ideas of jural right as debated by jurists as markers of how governments ought to cooperate in the duty of 'bringing the positive rules of international law into accordance with the standard set by the best jural ideal of the time'. ${ }^{222}$ In a passage similar to Lorimer's emphasis on community expression of rational will, Westlake sees these jural rights as contested rational positions emerging from the mass of social interactions among citizens - or for that matter, states - who live together and are tied by bonds that both serve their interests and mould their sentiments. ${ }^{223}$ Those bonds are not constructed or reformed by any 'preconceived idea' of perfect arrangements of rights, but rather endure and change through further interactions. ${ }^{224}$ Westlake sees no 'obvious reason' why these jural principles should be weaker in international society, but recognises the

218 See, eg, L Oppenheim (ed), Memories of John Westlake, with Portraits (Smith, Elder \& Co 1914); H Lauterpacht, 'Westlake and Present Day International Law' [1925] Economica 307; Johnson, 'The English Tradition in International Law', 440-42.

219 See J Westlake, Chapters on the Principles of International Law (CUP 1894) 28. While Maine did lecture and write briefly on international law, and took up a substantive interest in the development 'primitive' communities as well as the emergence of modern sovereignty and its connection with territory and empire, his works do not directly examine ideas of recognition: see, eg, HS Maine, International Law: The Whewell Lectures (Murray 1890); Lectures on the Early History of Institutions (Murray 1875). For an appraisal of Maine by his successor, see Paul Vinogradoff, The Teaching of Sir Henry Maine: An Inaugural Lecture (Frowde 1904). On Maine and Westlake, see L Benton, 'The Geography of Quasi-Sovereignty: Westlake, Maine and the Legal Politics of Colonial Enclaves' (IILJ Working Paper No 2006/5, New York University, 2006).

220 See Dicey's remarks on this point: Memories of John Westlake, 29.

221 Westlake, International Law: An Introductory Lecture (CUP 1888) 1-2.

222 Ibid, 8-12.

223 Ibid, 12.

224 Ibid. 
strength of the development in the latter as stemming from the 'habit of common action for common ends'; that is, international cooperation. 225

Whereas Lorimer's image of international society is of conflict between stratified ethno-national groups, the progress of which is a matter for their own internal political development as judged by European jurists, Westlake grounds his image of international society as necessitating a colonial, missionary project for the international lawyer to bring inferior civilisations up to the standards of Europe. In his 1888 lecture Westlake said

I deprecate the ignoring of personal responsibility quite as much with a view to the effect which the conduct of a great state may have on the destinies of other populations, especially of those which, as possessing less power or a lower civilization, are exposed to be most seriously affected by our action or our abstinence from action, while least able to help themselves. ${ }^{226}$

The 'sound[ness]' of international law, politics, and the treatment of inferior races demanded a sense of duty that could not be 'roused' by only studying 'abstractions'.227 Westlake's view here has a longer provenance resting on Christianity and colonialism. In an 1868 essay, Westlake defended the Church of England as an important and useful tool of colonialism; a 'powerful instrument for England in executing her task of spreading the best civilization over the world'. ${ }^{228} \mathrm{He}$ envisaged that role as one of cultural transformation of colonised peoples, necessitated by Britain's mission to found 'new Christian states' and act as 'mediators between Christianity and Heathenism, from savage Africa to the most philosophical sects of India and China' so as to bring their best ideas to Europe. 229

This kind of thinking - progress, the mediation of ideas, personal dutyunderlies Westlake's conception of international law in general. International law for Westlake comprised all general statements about 'human action not internal to a political body': descriptive knowledge about states, evaluations of their 'strength', appraisals of their degrees of subordination to each other. ${ }^{230}$ This better grounded Westlake's image of the international lawyer as missionary and the discipline's claims to the mantle of science:

I have not chosen to define International Law as the science of the rules prevailing between states, and to treat as subsidiary the question of how far those rules are applicable to semi-sovereign states or to half civilized or uncivilized populations. I have chosen to put in the front the idea of action, which carries with it the ideas of duty and responsibility, and to define International Law as dealing with all human action not internal to a political body. From this point of view the subject is seen to have a real unity, though the rules of action will naturally differ in the circumstances. ${ }^{231}$

225 Ibid, 13.

226 Ibid, 15 .

227 Ibid.

228 J Westlake, 'The Church in the Colonies' in WL Clay (ed), Essays on Church Policy (Macmillan 1868) 226, 232.

229 Ibid, 236-37.

230 Westlake, Inaugural Lecture, 1.

231 Ibid, 15. 
Westlake's later works sought to articulate these rules and their unity by gleaning specific principles from a close examination of the uses of international law within international society in recent decades.

Westlake's concept of recognition rests on a range of other legal ideas: consular jurisdiction for the evaluation of non-European states, and territory, sovereignty and government for the dispossession of and refusal to recognise indigenous polities. These views are first articulated in his 1894 Chapters on the Principles of International Law, and later revised and presented in a more systematic form in his 1904 textbook. Like Twiss, Westlake examined the concepts of government, treaty-making capacity, jurisdiction and sovereign personality in the context of African and Asian political communities, but unlike Twiss, he incorporated those ideas much more clearly into his concept of recognition, and in a more technical, legalistic and positivist language. Westlake's concept of recognition presented a more sanitised version of a worldview closely resembling Lorimer's, and one that was also more appealing to practically-minded international lawyers.

Westlake's foundational principles of international law were elements of a definition of the nature of international society. First, international society is the society of states with European civilisation: 'States are its immediate, men its ultimate members.' 232 Westlake confines current international society to first, all European states, secondly, American states that on gaining independence inherited European international law, and thirdly 'a few Christian states in 'other parts of the world': Hawaii, Liberia and the Orange Free State, but not Abyssinia. ${ }^{233}$ In seeking to maintain 'the rules of good breeding', international society could, like a cricket club or trade union, maintain its rules by shunning those who do not observe them. 234 International society to Westlake was 'not a voluntary but a necessary society': states could not adhere to its rules only in part, and any state that is 'geographically proximate' to the society but not bound by its rules would be a source of 'intolerable inconvenience and danger'.235 Consequently, new states emerging from older members must take up its rules entirely, but in dealing with nearby outsiders seeking admission, current members could admit them to 'parts of its international law without necessarily admitting them to the whole of it'. 236

Westlake treated this gradual admission to international society as a question of consular jurisdiction. Whereas Twiss saw consular jurisdiction as a proposal for furthering civilisation in 'uninhabited' regions, Westlake saw it as a mark of partial inclusion. '[S]ubstituted for rules of jurisdiction belonging to ordinary international law' in Japan, China and Turkey, consular jurisdiction presented 'an instance of the way in which all human institutions, being free and not mechanical products, shade off from one to another'. 237 While Europeans and Americans abroad cannot be assured of adequate protection against non-European governments, who each hold 'unfamiliar

232 Westlake, Chapters, 78.

233 Ibid, 81-82.

234 Ibid, 6-7.

235 Ibid, 79.

236 Ibid, 82 .

237 Ibid. 
interests arising out of [their] foreign civilization', 238 the presence of effective consuls within Turkey, Persia, China, Japan and Siam mean those states must be recognised as possessing stable legal orders 'different'-rather than explicitly inferior - to those of Europe. ${ }^{239}$ The maintenance of that jurisdiction, and this status, relies nonetheless on 'local support' which requires (and evidences) that a non-European state possesses

an old and stable order of its own, with organized force at the back of it, and complex enough for the leading minds of the country to be able to appreciate the necessities of an order different from theirs. Such countries must therefore be recognised as being civilised, though with other civilisation than ours. $^{240}$

To Westlake, commonality of civilisation prerequisite to full membership of international society was possible through development- 'civilisation has grown up by degrees, and populations have become included in it among whom it did not originate'. ${ }^{241}$ The touchstone of this civilisation, however, remains the confidence that European powers maintain that the legal rights of their citizens will be treated on an equal basis with that of native citizens, without any unfair discrimination, in courts backed by a government holding effective control over a territory. Non-European states may be partly recognised through treaty relations, but the attainment of full status depends on a system of consular jurisdiction acceptable to Europe.

In the 'uncivilised regions', Westlake contended that an absence of statehood precluded the possibility of recognition of indigenous tribes - except as part of the processes of assimilating them into a colonial power. In making this argument, Westlake relies on the ideas of territorial sovereignty, property, treaty-making capacities, and government. Again, these ideas are similar to those used by Twiss, but Westlake constructs a more coherent doctrinal position with a stronger, clearer position for recognition. While territorial sovereignty resembles property in land it differs in exclusiveness and alienability: one state can exclude another from acts in its territory, and, subject to the rules of international society, one state can alienate its sovereignty. ${ }^{242}$ With the breakdown of feudalism the 'confusion' between property and government became clear. ${ }^{243}$ For Westlake the origins of title to territory as sovereignty in the old civilised world and old states of 'different' civilisation cannot be discussed now except as a series of cessions or conquests; he turns instead to "new countries' to outline its expansion beyond Europe. ${ }^{244}$ Where a civilised state founds a colony, the title to its land 'may sometimes be deduced by the proprietors from a situation of fact which existed before the civilised government was established, and which that government has accepted and clothed with its sanction': that is, either the presence of 'advanced' natives holding ideas of property or the settlement of European

238 Ibid.

239 Ibid, 102.

240 Ibid.

241 Ibid, 104ff.

242 Ibid, 129-36.

243 Ibid. Recall that Twiss also noted a 'confusion' around property and sovereignty related to feudalism.

244 Ibid, 134. (Those states of 'different' civilisation include 'Turkey, Persia, China, Japan, Siam': at 102.) 
pioneers. ${ }^{245}$ But generally, title to land in a colony 'is traced from a grant by the state', in turn authorised by that state's own territorial sovereignty, and involves the state assuming property in all the land that it was 'not morally compelled to acknowledge as belonging to natives or to the pioneers' ${ }^{246}$ In either case, concludes Westlake, property originates in sovereignty.

For Westlake this is a question of recognition; not of a new state, but of the extension of territorial sovereignty as a positivist question of fact: "what facts are necessary and sufficient in order that an uncivilized region may be internationally recognised as appropriated in sovereignty to a particular state?'. ${ }^{247}$ But answering this question lies with international society: the rights of native tribes are to be 'left to the conscience of the state' that has been recognised as appropriating their territory. ${ }^{248}$ Westlake states that while this proposition is 'at first startling' it 'becomes almost axiomatic' because international society is too weakly organised to enforce rules 'for the benefit of outsiders', and must leave that action to individual members alone. ${ }^{249}$

This new role for recognition reflects the outcome of the Berlin Conference, to which Westlake now turns to analyse carefully. Berlin established the system whereby a European state that had made 'an accession of territory on the coast of Africa' would notify the other powers, which would then have an opportunity to object. ${ }^{250}$ In Westlake's view this outcome bolstered the conference's central aim of facilitating and expediting colonial expansion-as he put it, 'avoid[ing] collisions between [conference] members' - by clarifying their coastal claims, and preventing any European objections that 'native title ... had not been duly ceded'.251 Westlake envisages a range of questions which might be raised by other powers in making those objections:

Is any territorial cession permitted by the ideas of the tribe? What is the authority - chief, elders, body of fighting men-if there is one, which those ideas point out as empowered to make the cession? With what formalities do they require it to be made, if they allow it to be made at all? These questions are too obscure among uncivilised populations, or, if they are clear to them, too obscure for the whites who are in contact with them ... ${ }^{252}$

Westlake endorses this approach as necessary for avoiding unnecessary conflicts, without causing injustice to the natives, who now gain 'more than the common claim of the governed[:] they have the claim of the ignorant and helpless on the enlightened and strong; and that claim is the more likely to receive justice, the freer is the position of the governors from insecurity and vexation'. ${ }^{253}$

245 Ibid, 137.

246 Ibid.

247 Ibid.

248 Ibid, 138.

249 Ibid, 139.

250 Ibid, 138-39.

251 Ibid, 139.

252 Ibid, 139-40.

253 Ibid. 
Both the denial of the sovereignty of native tribes and their incorporation as protected by the coloniser rested on a purported lack of government, which Westlake announces as the 'international test of civilisation'. ${ }^{254}$ Where native tribes govern themselves by, say, the standards of 'Asiatic empires', Westlake concedes that the rules of European international society require that they be 'take[n] account of' and have their title to territory acknowledged. ${ }^{255}$ But where this cannot be shown, "the first necessity is that a government should be furnished'. ${ }^{256}$ While that duty falls to the colonising power, Westlake also uses the absence of government to erase earlier agreements: treaties between European officials or private subjects with native tribes that purport to cede sovereignty cannot be taken to do so and will not be recognised as conferring international title because tribes lack the ability to consent. ${ }^{257}$ This position is aimed explicitly against the claims of Portuguese jurists that treaties concluded between Portugal and various tribes had the effect of ceding sovereignty to Portugal. 258

Instead, acquisition of territory through taking up the responsibilities of government proceeds by recognising an indigenous polity-not as an international subject, but rather as a domestic, dependent nation immediately incorporated into the colonising empire. Westlake praises a detailed treaty made with the Makololo, 'chiefs of a nation which for intelligence and character ranks very high among those which must be still called uncivilized', in which those chiefs explicitly promised peaceful relations, allowed British subjects freedom of movement and trade in accordance with local laws, agreed that disputes would be settled by a representative of the British Crown, and guaranteed that they would not cede territory to any other power without British consent. ${ }^{259}$ Westlake interprets this as evidence that the Makololo understand their lack of ability to cede territorial sovereignty or to consent to 'the right which the queen [sic] may one day come to exercise' to found a government there. ${ }^{260}$ This interaction constitutes the recognition of the Makololo in an imperial, internal sense, as a domestic, dependent nation:

[I]n the mean time [that is, prior to establishing a regular government] the Makololo are recognised as a nation under their chiefs, capable of entering into relations with the queen's government [sic] in matters within their comprehension ... Every foundation is therefore laid, to the extent admitted by the nature of the case, for the future development of territorial sovereignty in the civilised and international sense, and for the permanence under it of such rights as the Makololo already possessed. ... the Makololo are admitted as a 'domestic dependent nation' ... ${ }^{261}$

Having concluded that uncivilised tribes can at best gain recognition as domestic dependent nations, Westlake turns to show that inchoate titles to territorial sovereignty within uncivilised regions must be perfected by occupation. Occupation

254 Ibid, 141.

255 Ibid, 141-42.

256 Ibid, 142-43.

257 Ibid, 144-45.

258 See ibid, $145-51$.

259 See ibid, 153.

260 Ibid, 154.

261 Ibid, citing Cherokee Nation v State of Georgia (1831) 30 US 1, 17. 
carries the duty of establishing an authority to "which may protect the natives with whom contact has become inevitable' and capable of protecting 'the civil rights essential to European or American life'. ${ }^{262}$ Perfecting international title requires first a clear declaration of the particulars of the title by a state, and secondly the actual fulfilment of those duties of occupation at some point. ${ }^{263}$ But Westlake offers a stern response to the claim, again advanced by Portuguese jurists, that a civilising influence may perfect international title: 'the value and efficacy of such efforts are sure to be differently appreciated by the power which builds on them and by the power against which the title is invoked'. 264 Progress in the civilising mission strengthens the coloniser's claim to title, which other Europeans ought not question. If native tribes had moved towards European civilisation even 'without the training and discipline which results from European government or control', the state that had failed to establish its authority there was itself solely to blame for losing that 'prospective benefit'.265 It seems, then, that manifest failures in that mission might allow an indigenous nation recognition on its own terms.

Finally, Westlake turns to protectorates and their relation to independence and recognition. A protectorate in the civilised world is a state with semi-sovereign international status, in that its foreign affairs are 'managed for it' by the protector state that also grants it some degree of internal freedom. Yet because uncivilised regions lack states Westlake holds that there can be no protectorates there. ${ }^{266}$ To Westlake, a protectorate claim effectively carries the same obligation of establishing governmental authority as a new possession. The recent usage of this term has arisen, Westlake suspects, for the practical reason that if a state 'wearies of its task' abandoning a protectorate carries a lesser loss of prestige, but also gives 'greater freedom' in the steps towards acquisition. 267

In his 1904 textbook, Westlake not only repeated the points above but further bolstered and systematised them by presenting his concept of recognition in the form of a taxonomy. Westlake classifies states based on governmental independence and foreign relations: fully independent states exercise governmental control over their territory and 'to some extent' their subjects, and their external sovereignty is not dependent on the type of government, only its capacity to be part of international society through foreign relations; semi-sovereign or dependent states are more or less free in internal government but constrained by their protectors in foreign relations. ${ }^{268}$ Westlake then outlines his taxonomy of seven processes by which new members have joined 'full international society'. First, recognition by political action (Russia, after Peter I). 269 Secondly, by 'being freed' from consular jurisdiction (Japan as of 1904). ${ }^{270}$ Thirdly, by the creation of a state with a European mode of government in

262 Westlake, Chapters, 159.

263 See ibid, 160-66.

264 Ibid, 175, and see at 174-77.

265 Ibid, 177.

266 Ibid, 177-78, and see at 178-79 (on the misuse of the term 'protectorate').

267 Ibid, $183-84$.

268 See J Westlake, International Law: Part I: Peace (CUP 1904) 20-27, 40-41.

269 Ibid, 45.

270 Ibid, $45-46$. 
an uncivilised region, the most important example being the Congo State, which was admitted due to its international private association attaining 'so solid a footing' that it concluded treaties with the United States and European powers and was admitted to sign the General Act of the Berlin Conference, as well as Liberia: 'Here we see European institutions, learnt on civilised soil by men of other blood and transported by them to another region of the earth, accepted as equivalent of European blood'.271 Fourthly, by voluntary subdivision within an old member to create a new state, as in the separation of the thrones of Portugal and Brazil.272 Fifthly, through arrangements between the Great Powers in resolving independence struggles through agreement between European powers, as in Belgium, 'Rumania' and 'Servia', and Montenegro. ${ }^{273}$ Sixthly, belligerent secession recognised by the state from which the new state has separated, as in the case of the United States, the Spanish South American republics, and Greece. ${ }^{274}$ Finally, Turkey's partial admission to the public law and system of Europe, which, while still involving consular jurisdiction by European states, guaranteed the protection of Turkey's territorial integrity and her apparent inclusion in decisions on questions of changes to territories within Europe, a central tenet of the Westphalian system. ${ }^{275}$

Westlake's concept of recognition reflects a more varied international society and is less explicitly racialised than Lorimer's. Yet it clearly replicates and advances the latter's division of the world into civilised, semi-civilised and barbarous, and is given new purpose in justifying and legalising colonial activities after the Berlin Conference. Westlake entrenches Lorimer's progressive movements through stages of recognition by providing more detailed explanations of that process, newly based in questions of law and fact: the gradual removal of consular jurisdiction or through colonial appropriation of uncivilised lands, which in turn rely on ideas of jurisdiction, territorial sovereignty, treaty-making capacity and governmental systems which are now incorporated into the new uses and meanings of recognition.

\section{Oppenheim's neutralisation of recognition}

Oppenheim's International Law, appearing in 1905, completes Westlake's turn to technical, positivistic international lawyering and the sanitisation of the concept of recognition. Educated in Germany and Switzerland, Oppenheim moved to Britain in 1895 and became a citizen in 1900. He taught at the London School of Economics before succeeding Westlake in the Whewell Chair in 1908. Oppenheim saw the role for legal philosophy as 'lay[ing] bare the religious, ethical, economic, sociological, and ethnological roots of legal institutions'.276 Theory must try to understand and define the influence of political ideas on legal institutions, but also always refrain from 'fight[ing] for and against certain political ideas' because these lie within 'the unsafe

271 Ibid, 46.

272 Ibid.

273 Ibid, 46-47.

274 Ibid, 47, 57-58 (noting this form applies to semi-sovereigns who 'shake off' dependency).

275 Ibid, 47-48.

276 L Oppenheim, 'A German System of Legal and Economic Philosophy' (1907) 8 Journal of the Society of Comparative Legislation 124, 128. 
vessel of party politics' far from the 'safe ground' of jurisprudence. ${ }^{277}$ As Kingsbury has argued, this apparently strict separation of law from politics, far from being 'neutral' about political projects, was the conception of law that best furthered Oppenheim's own moral and political values. 278 Oppenheim's concept of recognition concords with that view: ostensibly it omits substantive criteria like internal government control in favour of the simple consent of current members of the family of nations. While civilisation is retained as a requirement of membership, Oppenheim's discussion of its meaning seems to empty it of any substantive political content. Yet far from removing chauvinist European superiority, Oppenheim's project of extending international law's reach subsumes that hierarchy by entrenching states as the only persons recognisable in international law. In removing and neutralising significant parts of the conceptual content built up by jurists like Lorimer, Twiss and Westlake, Oppenheim grants recognition a more prominent teleological, ideological and political role within international law itself. The great influence of Oppenheim's work $^{279}$ and concept of recognition make his innovations here especially important.

In defining international society and its law, Oppenheim simultaneously makes civilisation central and strips it of clear substantive criteria. For Oppenheim, international law is the body of customary and conventional rules binding on civilised states in their intercourse with each other. ${ }^{280}$ All law is based in common consent of those it binds, and international law's basis is in the common consent of members of the 'Family of Nations'. ${ }^{281}$ International law neither extends as far as humanity itself nor only to Christian civilisation but instead is limited to members of the Family of Nations. ${ }^{282}$ To be admitted to the Family of Nations a state 'must, first, be a civilised State which is in constant intercourse with members of the Family of Nations'. Second, the state must 'expressly or tacitly consent to be bound for its future international conduct by the rules of International Law'. Third, 'those States which have hitherto formed the Family of Nations must expressly or tacitly consent to the reception of the new member'.283

Oppenheim sees the last two requirements as 'so obvious that they need no comment', but concedes that civilisation is somewhat more difficult. Civilisation is not confined to Christian civilisation, but must be 'conditioned as to enable the respective State and its subjects to understand and act in conformity with the principles of the Law of Nations'. ${ }^{284}$ Compared with the elaborate disquisitions of earlier jurists and their explicit use of European or Christian to give 'civilisation' conceptual content,

277 Ibid.

278 See B Kingsbury, 'Legal Positivism as Normative Politics: International Society, Balance of Power and Lassa Oppenheim's Positive International Law' in M Stolleis and M Yanagihara (eds), East Asian and European Perspectives on International Law (Nomos 2004) 139.

279 On which, see A Perreau-Saussine, 'A Case Study on Jurisprudence as a Source of International Law: Oppenheim's Infleunce' in M Craven, M Fitzmaurice and M Vogiatzi (eds), Time, History and International Law (Nijhoff 2007) 91.

280 L Oppenheim, International Law: Peace (Longmans, Green and Co 1905) vol 1, 3-4.

281 Ibid, 15 ff.

282 Ibid.

283 Ibid, 31 .

284 Ibid. 
Oppenheim's definition of 'civilisation' is vague and seemingly stripped of Eurocentric ideological, religious or political content. Further, any conceptual content to civilisation seems effectively subsumed by the second general criteria of willingness to abide by current international law. The vagueness here might be due to Oppenheim's stated intention to phrase ambiguous terms 'intentionally ... because the actualities on which they are based are not altogether clear', 285 and civilisation is clearly ambiguous (even to Twiss and Westlake). Another possibility is that by 1905 , civilisation is both too contested and no longer a particularly useful criterion for understanding the concept of recognition because 'pressing circumstances' have obliged 'Christian States ... to receive several non-Christian states into the community of States'. 286 Either way, Oppenheim both makes civilisation central and refrains from stating any clear religious, political or ideological criteria of civilisation.

But in accounting for the development of international law, Oppenheim clarifies what kinds of polities he considers 'civilised'. Oppenheim sees the present coverage of international law as a "product of historical development, within which epochs are distinguishable marked by successive entrances of various States into the Family of Nations'. The first three are uncontroversial: first, the old Christian states of Europe; secondly the Christian states outside of Europe in the Americas, Liberia and Haiti; thirdly, Turkey's 1856 entry, with which international law 'ceased to be a law between Christian States solely'.287 The fourth epoch involved the entry of Japan, which, since the war with China in 1895, can no longer be doubted as a 'real and full member' and is now a Great Power. ${ }^{288}$ The fifth epoch is the partial inclusion of states like Persia, Siam, China, Korea, Abyssinia, whose position remains 'doubtful' on the basis of their civilisation. While they are 'certainly civilised', that civilisation has not yet attained a level at which their governments and populations are able to understand and carry out all the commands of international law. ${ }^{289}$ Although treaty, trade and diplomatic interactions between them and Europe are clear, and despite Oppenheim's prediction they will 'certainly succeed' in attaining that level of civilisation through education their populaces and enacting modern reforms, without having completed that transition they cannot be received 'as full members into the Family of Nations' and must remain 'for some parts within the circle' and for others outside. ${ }^{290}$ The Congo Free State forms the sixth epoch, joining the Family of Nations after the Berlin Conference. ${ }^{291}$

Oppenheim is comfortable with degrees and divisions in the ideas of sovereignty, independence and statehood where these are necessitated by the facts of international life, and is content to refrain from general rules if special cases are the norm. ${ }^{292} \mathrm{He}$ uses the language of international personality to capture the diversity of international life. Sovereign states - a people living in community within a territory,

285 Ibid, viii.

286 Ibid, 32 .

287 Ibid, $32-33$.

288 Ibid, 33. Oppenheim does not mention consular jurisdiction, contra Westlake.

289 Ibid, 33-34.

290 Ibid, 34.

291 Ibid, 33-34.

292 Ibid, 101-103. 
with both a government that represents the people and rules according to the law of the land as well as a sovereign government, independent of any other 'earthly authority'293 — are international persons. But 'imperfect' or 'not-full' states, as well as 'apparent, but not real' international persons can also exist - states within federations, recognised insurgents and the Holy See, for example - but these are only partly treated as international persons, "without becoming thereby members of the Family of Nations'. ${ }^{294}$ Suzerains, protectorates and states within federations may hold supreme authority in some tasks, but in others rely on the authority of another state, and in this sense are always anomalous but tending, as 'history shows', to gain full sovereignty or disappear into province status. 295

Unlike the jurists examined above, Oppenheim's concept of recognition is less concerned with identifying the 'marks' or factual characteristics of a polity that would make it capable of recognition. Instead, he emphasises the process of acknowledgement by the Family of Nations; it is for current members to decide the criteria of statehood, the processes of recognition, and to assess whether they have been met in a would-be newcomer. A political community may well exist as a state, but absent recognition by other states it remains outside of international law, expressed in Oppenheim's oft-cited statement of what would become the central plank of the constitutive theory of recognition: 'A State is and becomes an International Person through recognition only and exclusively.' 296 Oppenheim acknowledges that '[m]any writers do not agree with this opinion'-arguing for example that secessions from existing recognised states includes immediate international personality and entry as of right into the Family of Nations, as in the case of Belgium in 1831-but he insists that the 'real facts of international life' run against this view. ${ }^{297}$ Prior to recognition states hold no international rights and cannot claim a right to be recognised, and while states may still exist without recognition, absent recognition the Family of Nations 'takes no notice' of it. ${ }^{298}$ Recognition can occur through formal declarations, the reception of diplomats, appointment of consuls or conclusion of treaties. ${ }^{299}$ While it is usually practically impossible to deny recognition, Oppenheim states that the decision 'is not a matter of International Law but of international policy'. 300 Although conditions may be imposed on newcomers, ${ }^{301}$ recognition of a new form of government does not involve any question of legitimacy, and merely signifies that current members are ready to deal with the new government. 302

With recognition comes international personhood, though for Oppenheim the facts of international life mean that the meaning and characteristics of that personhood

293 Ibid, 100-101.

294 Ibid, 99-100.

295 Ibid, 101-102.

296 Ibid, 108-109.

297 Ibid, 109.

298 Ibid, 109-10.

299 Ibid, 110, 471 (arguing contra Hall that the appointment of consuls, usually for commercial purposes, constitutes indirect recognition).

300 Ibid, 111.

301 Ibid.

302 See ibid, 403-405. 
are not stable. First, he strongly rejects ideas of 'fundamental rights' attaching to states, described and debated under headings like existence, self-preservation, equality, independence, territorial supremacy, intercourse and reputation. ${ }^{303}$ These ideas collect 'numerous real rights and duties' but they arise from customary recognition among members of the Family of Nations, not from inherent aspects of states. ${ }^{304}$ Secondly, he allows for a great deal of flexibility in different kinds of international persons depending both on facts and acceptance by other members of the Family of Nations. Recognition of a change in government type does not change international personality, ${ }^{305}$ though changes to independence-becoming part of a federal state, coming under suzerainty or a protectorate-do. Vassals and protectorates may hold 'some small position' of their own in the Family of Nations as a 'portion' of the suzerain or protector state, depending on their capacities for relations with other members, such as powers to send and receive envoys of their own (as in Bulgaria and Egypt) or conclude treaties with the approval of the protector (as in South Africa). ${ }^{306}$ Thirdly, while there is no essential difference between Christian and non-Christian States, civilisational differences are differences of 'kind' and 'position' but do not warrant exclusion from the Family of Nations. Where individual states send and receive envoys or conclude treaties they indicate that in those respects they recognise and receive a non-Christian state into the Family of Nations. ${ }^{307}$ In particular, nonChristian states are outside the Family of Nations for the purposes of war, and may be treated according to discretion only. 308 But Oppenheim predicts that 'with the progress of civilisation' non-Christian states will 'become sooner or later International Persons in the full sense of the term'. 309

With this passage the issue of Oppenheim's vagueness as to the ways in which non-Christian states are inferior arises again, now specifically in relation to recognition. While, like Westlake, Oppenheim criticises the inferiority of their peoples and governments, this does not have any real effect on status or capacity: Turkey to Oppenheim seems to be a full member of the Family of Nations despite the persistence of consular jurisdiction. With 'development' — though the kind or extent is never clearly laid out - non-European states will eventually attain European-standards of civilisation. In the meantime, treaties signed in various subject areas will extend the reach of international obligations. Given the reference to discretion in warfare and Japan's ascension on the basis of its war with China in 1895 (though it is not clear whether the victory itself or Japan's 'humane' conduct of warfare is the significant factor) Oppenheim may simply doubt that the conduct of these states in warfare would match European rules, absent any practice of these states to suggest otherwise. A state may also be a member of the Family of Nations by virtue of being a protectorate of a full sovereign, as in the case of Abyssinia prior to 1896 and Madagascar. ${ }^{310}$ Lower

303 Ibid, $158 \mathrm{ff}$.

304 Ibid, 159 (and for each particular right see 160-78).

305 See ibid, $115-16$.

306 See ibid, 116-17, 133-38 (on vassals and protectorates).

307 Ibid, 148-49.

308 Ibid, 149.

309 Ibid.

310 Ibid, 139-40. 
civilisation still remains as a label, but it is essentially bereft of content or consequences in that the vague 'parts' for which non-European states are members of the Family of Nations bound by international law are those rules to which they have (ostensibly) consented.

By making civilisation central and yet neutralised in the concept of recognition, Oppenheim moves to fixate on the state and removes much of the substantive content given to ideas like civilisation, Europeanness and government that played such important roles in the works of Westlake, Twiss and Lorimer and their exclusion of various non-European political communities. While he does provide an exhaustive list of states present in the world of 1905,311 Oppenheim never provides an example of a state that does exist but nevertheless still falls entirely outside of the membership of the Family of Nations. Like Westlake, he sees small tribal political communities as clearly not falling within the definition of state, and therefore not capable of being recognised. But while Oppenheim follows Westlake's thinking on the creation of new states in Africa, he argues that recognition - and not ideas of progress, territorial acquisition, or colonial improvement on which Westlake draws - plays a definitive role. Oppenheim simply argues that regardless of how territory was acquired, the formation of a new state is a matter of fact, but it is only through recognition that it 'becomes a member of the Family of Nations and a subject of International Law'. 312 What changes here from Westlake's account is the absence of express emphasis on a colonial mission, of spreading civilisation or European-style government, for understanding when and where authority is exercised over new territory. These ideas are not disavowed in Oppenheim's text, but they are subsumed by his focus on states and positive rules established by clear common consent.

The signal effect of this move is the shift away from the colonial context as explicitly relevant for the concept of recognition. In addressing colonial acquisitions, Oppenheim treats these as simple questions of territorial control and thus of no real concern to international law. As García-Salmones Rovira points out, Oppenheim, contrary to most international lawyers of the day, expressed little concern about an absence of formal administration over colonies and their peoples. 313 Because the state is the sole focus of international law, these projects are, to Oppenheim, outside of the 'dominion of the Law of Nations': 'all such acquisition is made either by occupation of hitherto uninhabited land ... or by cession from a native tribe living on the land'. 314 A state can only occupy territory that is not part of any state (either uninhabited or inhabited only by native tribes), and even the territory of a state 'entirely outside the Family of Nations' must be conquered or ceded. 315 Taking possession, establishing an administration over the territory 'of and for the acquiring State' is the only relevant test for occupation, and it is only when other members of the Family of Nations recognise this acquisition as part of the coloniser's territory, or as a new separate state, that international law comes to be relevant. 316 Agreements with native tribes 'by

311 Ibid, 154-57.

312 Ibid, 264.

313 M García-Salmones Rovira, The Project of Positivism in International Law (OUP 2013) 99.

314 Oppenheim, International Law (1905), 265.

315 Ibid, 276.

316 Ibid. 
which they submit themselves to the sway of the occupying State' are irrelevant and have at best moral value: because tribal chiefs are not heads of state but only heads of tribes, they cannot engage in state-state relations, and hence cannot properly cede territory or conclude treaties that have anything more than 'moral value'. 317 Consequently, the legal consequences of particular modes of colonial territorial acquisition that were so important for Westlake and Twiss are either irrelevant or merely titles to be recognised or not by the community of nations.

What then does Oppenheim's work suggest about the state of recognition just prior to the First World War? Oppenheim's second edition, appearing just before the outbreak of that war, includes updates to reflect the crises in the Balkans and the breakdown of the 1878 Berlin Congress, and noting the presence of China, Persia and Siam at the Hague Peace Conferences in 1899 and 1907, as well as Great Power interventions in Morocco and Abyssinia in 1906 and 1907.318 Oppenheim adds in this edition that some of these states 'are at present in a state of transition, and some of them are the subjects of international arrangements of great political importance'. 319 Oppenheim's world is one in which the nation-state is no longer a solely Christian or European construct: Turkey and Japan have achieved full statehood, and in Japan's case this position as an equal of Europe was only bolstered by its victory against Russia in the 1905 Russo-Japanese war. Statehood is relatively easily achieved in this world, and while even the most basic interactions with current members will constitute international personality and membership, small states are present at new large international conferences. Finally, Oppenheim represents some move away from the nineteenth century consensus that the Great Powers held central, determining status in questions of recognition, noting that their status and influence is a result of power and obedience, and not derived from law. ${ }^{320}$ Amidst a large increase in new small states, and the relatively equal engagement through law between all states, European and non-European alike, power is of-seemingly-lesser importance.

\section{CONTESTATION In THE INTERWAR PERIOD: Williams, BATy AND LAUTERPACHT, $1915-50$}

Oppenheim's works shifted focus to the state, subsuming race, civilisation and government into that focus, and making recognition the marker of membership of the Family of Nations. Oppenheim's relative lack of emphasis on civilisation as such, is an important element of the traditional (and now frequently challenged) narrative that positivist international law flourished in the interwar period partly because it focused on, and reified, an abstracted state that remained in reality reflective of the European nation-state. ${ }^{321}$ After the end of the First World War, amidst major upheavals in international organisation in the League of Nations system and the new technical and advisory prominence for international lawyers within it, imperialist, colonialist and

317 Ibid, 277-81.

318 L Oppenheim, International Law: A Treatise (2nd edn, Longmans, Green and Co, 1912).

319 Ibid, 156.

320 Oppenheim, International Law (1905), 163ff, citing Lorimer and Westlake as maintaining the contrary view.

321 See, eg, García-Salmones Rovira, Project of Positivism. 
civilisational thinking persisted in different guises. ${ }^{322}$ The collapse of the German, Austro-Hungarian, Ottoman and Russian Empires, the shifts in colonial rule with the new mandate system, and the move from dominion to semi-independence within parts of the British Empire, created a raft of new political entities of varying levels of independence, statehood and protectorate status throughout the world of the 1920s. Statehood and its nature became urgent problems of the interwar period, but not only confined to relations between European and non-European entities. The League also sought to avoid the repetition of the horrors of the First World War, which had shaken widely held convictions about the superiority of European civilisation and confidence in liberal progressive ideas, through the project to outlaw war. Peace was to be attained through international organisation. The League's principle of universality meant that it was to be open to '[a]ny fully self-governing state, Dominion or colony' that accepted to be bound by international law and an admission vote by two-thirds of the current members, ${ }^{323}$ reflecting criteria seen in the works of Twiss, Westlake and Oppenheim. But, as one commentator at the time put it, this admission system 'inevitably brought [the League] into conflict with the theories of international law elaborated in pre-League days' most importantly the concept of recognition and specifically whether admission superseded, was synonymous with, or was entirely separate from recognition. 324

Against this backdrop of new states, new revolutions, new modes of colonial control, and the mainstream dominance of positivist methods in international legal argument, recognition once again became a central question for British interwar international lawyers. In their works, it attains its status as a basic concept in international law. In various ways, Sir John Fischer Williams, Thomas Baty and Hersch Lauterpacht - the major British thinkers on recognition in the interwar period-present ruptures with earlier British theories as well as those of their continental contemporaries. They criticise civilisational superiority as well as the centrality of the state which characterise positivist accounts of recognition. Their lengthy and close attention to debates about the meaning of recognition incorporate and react to a variety of projects of the day: for Williams, equalising international society and outlawing war, and for Baty and Lauterpacht-albeit in very different ways - the project of securing a genuine legal frame to political actions of states. Each of these jurists articulates a powerful vision of law in international society and diplomacy, and the interwar period sees political projects tied much more closely to their concepts of recognition. These works also provide some indications of slight 'democratisation' of the concept of recognition as a central question for interlocutors on international politics. It is thus in the interwar period and in these writings that recognition can be seen as finally emergent as a basic concept in international law.

322 See, eg, D Kennedy, 'The Move to Institutions' (1986) 8 Cardozo LR 841; N Berman, Passion and Ambivalence: Colonialism, Nationalism, and International Law (Martinus Nijhoff 2012); Anghie, Imperialism, Sovereignty and the Making of International Law, ch 3; JE Nijman, The Concept of International Legal Personality (TMC Asser Press 2004) ch 3; K Wohlström, 'On Disillusionment and Its Limits: Images of the Interwar Legal Project in International Relations and International Law' (2010) 80 BYIL 361. For a general history, see, eg, EH Carr, The Twenty Years' Crisis 1919-1939 (Macmillan 1939).

323 Covenant of the League of Nations (opened for signature 28 June 1919, entered into force 10 January 1920) [1920] ATS 1, art 1.

324 LM Friedlander, 'The Admission of States to the League of Nations' (1928) 9 BYIL 84, 86. 


\section{A. Williams: recognition in service of equality and peace}

Sir John Fischer Williams was the first British jurist to write extensively on the concept of recognition in the interwar period. Williams saw the concept of recognition, when combined with a fairer, representative and universal League of Nations that entrenched diplomacy in accordance with international law, as the best hope for equalising international society and avoiding war. Williams was a liberal humanist international lawyer working within the institutions of the League of Nations throughout the interwar period, and is primarily remembered as a superb practitioner and adviser to the British Government, the British representative at the League and on the Versailles Reparation Commission (1920-30) and as the British Member of the Permanent Court of Arbitration (1936-47). ${ }^{325}$ While Williams might be seen as a consummate 'British' international lawyer oriented to practice over theory, ${ }^{326}$ he still held a firm interest in concepts, foundations and the structure of international law and published in academic forums. In accordance with his intellectual lodestars of Westlake, Arnold McNair and James Brierly, Williams understood the importance of focusing on concrete problems, rules and diplomatic practice even when considering more abstract international legal problems. Brierly's influence on Williams is substantial, and the latter's work on recognition can be seen as a more in-depth, philosophical articulation of Brierly's brief defence of the declaratory view. ${ }^{327}$ Yet, Williams frequently expresses unease with stricter forms of positivism and formalism associated with thinkers like Brierly and McNair. As reflected in his concept of recognition, Williams held that international law must contain general principles resting on broader ideals of progress, humanity, universalism and peace. In his view, the peculiarities and primitiveness of the interwar international legal system placed a higher burden of responsibilities on its practitioners than that which lay with the domestic practitioner, specifically to develop international law and to ensure its careful use: 'This activity [of international law] and these advances [since the First World War] show the necessity both of caution and of audacity. The needs of the world demand a bold advance, and the critical nature of the issues involved make a false step more perilous than ever before'. 328

Williams' first publication on recognition is his address to the Grotius Society in 1929 on new states and governments, in which he outlines a concept of recognition aimed at equalising international society. The meaning of recognition, which is 'nearly, but perhaps not quite, self-explanatory', is a straightforward declaratory one: recognition is the operation by which an existing state 'admits' that a new state exists and is part of international society, intimating readiness to or actually instituting relations with it, and in the case of a new government is the acceptance that it now

325 CW Jenks, 'Fischer Williams_-The Practitioner as Reformer' (1964) 40 BYIL 233, 284.

326 On which, see ibid, 244-45.

327 Lauterpacht treats them as promoting the same explanation of the declaratory theory: $\mathrm{H}$ Lauterpacht, 'Recognition of States in International Law', 442. See JL Brierly, The Law of Nations (OUP 1928) and Nijman, Concept of International Legal Personality, 131-49 (on Brierly's views of international legal personality).

328 JF Williams, Aspects of Modern International Law: An Essay (OUP 1939) 7; Jenks, 'Fischer Williams', 235. 
represents the old state combined with the continuation or renewal of relations. 329 Rather than looking to recent judicial decisions and diplomatic pronouncements, 330 Williams first examines juristic works, before moving to deductive arguments, and concluding with specific problems of the world and the League. By this time, constitutive and declaratory theories are clearly entrenched opposing views. Rather than 'weighing the authorities' on the 'sides' represented by Oppenheim against Bluntschli's rights approach, Williams considers it 'better to see to what practical conclusions we are led by the adoption of either theory' 331 by splitting the major issues of state recognition into 'two separate, if closely allied, propositions': '(1) Has 'recognition' a creative efficacy? Do States become States as a result of recognition and not otherwise? (2) Have bodies of men organised as States a right to 'recognition,' or are existing states free as a matter of International Law to give or refuse "recognition"?'332

What follows is a thoroughgoing critique and denial of 'creative efficacy'-Williams' term for the central point of the constitutive theory; that recognition 'creates' states, which he considers supported by 'great authority' 333 _ and more generally of positivist approaches to international law.

Central to this criticism is Williams' own attempt to neutralise the criteria of 'civilisation'. Despite the similarities with Oppenheim's less direct attempts to do the same, Williams is clearly less enamoured of the claimed civility of international society central to Oppenheim's view. Williams contends that if the 'civilised world' consists of people divided into states and international law regulates 'the relations of those States as subjects having rights and duties', then older States cannot claim any prerogative power of "making what is already a State into an "international person". 334 The positivist, thinks Williams, would dispute the definition of international law and insist on Oppenheim's account of it. 335 But positivism is 'not inconsistent with the view that the question whether a State is civilised is a question of fact and that, once [that fact] is established to the satisfaction of the general sense of mankind, or otherwise apparent, that State becomes ipso facto a subject of International Law.' 336 While humankind's status as the entity to be 'satisfied' remains somewhat unclear-is it the arbiter or standard of civilisation?-significantly, humankind, not merely European nations, is the referent for civilisation.

Like Oppenheim, however, Williams seems to remove substantive criteria from the idea of civilisation. With his post-First World War wariness of nationalism and the centrality of states, Williams does not equate civilisation with statehood. Rather he tries to remove its substantive aspects by analogising pre-war forms of international society to a formerly 'close corporation' now opened up beyond the members of a single controlling family, to any person resembling a state:

329 JF Williams, 'Recognition' (1929) 15 Transactions of the Grotius Society 53, 53.

330 Cf AD McNair, Oppenheim's International Law (4th edn, Longmans, 1926) vol 1, 142ff.

331 Williams, 'Recognition' (1929), 54.

332 Ibid.

333 Ibid, 61.

334 Ibid, 55.

335 Ibid, citing McNair, Oppenheim 's International Law (4th edn), vol 1, s 1.

336 Williams, 'Recognition' (1929), 56. 
... the conception of 'the Concert of Europe' as the body entrusted with the keys of civilised society has now only an historic interest ... when the close corporation with its governing body has disappeared, admission to the larger society which has taken its place cannot be regulated by the independent decisions of a number of separate and unrelated individual members of the society. Membership of the new society must be a right of all organised sovereign communities, whose civilisation permits them to understand and to recognise international duties - even if they fail occasionally, as we all fail, to discharge them. ${ }^{337}$

This passage reveals a significant conceptual shift. Williams purports to embrace the apparent removal of European control over admission to the society of nations, now too wide and diverse to remain the preserve of Europe. Notably, he acknowledges that a failure to follow international law in all instances should not place a community beyond recognition: what matters is the acknowledgement of international law's demands, which the War and the League should remind us, may be ignored or flaunted by even the oldest 'civilisations'. Rather than removing civilisation, Williams promotes a more ecumenical idea that (paradoxically for the times) should not be evaluated by Europe. '[H]uman society' can no longer, contra Westlake, be seen as an 'exclusive club' that leaves much of humanity 'beyond the pale under the general principles of morality [and] excluded from the reign of law'.338 Instead, 'civilised men organised in a definite territory under a sovereign government do not need to beg admission to international society; their State has ipso facto, by virtue of its mere existence, rights and duties, and, therefore, personality in the domain of International Law'.339

Williams' endorsement of an automatic right to recognition here turns towards naturalistic, cosmopolitan arguments to counter fixation on the state. Williams believes that international law also incorporates an element beyond consent in the 'general opinion of civilised mankind'. 340 By avoiding being 'hypnotised by the contemplation of states alone' and acknowledging they are but one form of human organisation, it seems impossible that legal principle would allow 'even a majority of States to deny to human beings, not their subjects, fulfilling the necessary conditions of civilised government, the right to enter international society.' 341 Institutional constraints, however, prevent this from occurring. Williams acknowledges that as much as he would prefer collective decisions along the lines examined above, absent the US and the USSR, the League cannot yet act as the central organ for recognition, and the question 'still remains the affair of individual States'. ${ }^{342}$ Once the League is actually all-inclusive, "we shall have again a central authority, better equipped and with a more regular authority than the old Concert of Europe, which will say the last word on any question of recognition of a new State.' 343

337 Ibid, 59-60.

338 Ibid, 60.

339 Ibid.

340 Ibid, 61.

341 Ibid, 61-62.

342 Ibid, 62.

343 Ibid. 
In his writings of the 1930s, Williams' vision for recognition as an instrument of inter-state equality expanded to include the role of ensuring peace. The 1929 paper was given just after the signing of the Kellogg-Briand Pact, which outlawed war as an instrument of national policy; at the beginning of the Chaco War between Bolivia and Paraguay; and just prior to the challenges to the League's authority that emerge with Manchuria and Abyssinia. ${ }^{344}$ In 1932 Williams returned to the Grotius Society to examine the League's adoption of the Stimson Doctrine, which provided that any 'situation, treaty or agreement' that is contrary to another treaty (including the Covenant) would not be 'recognised', and the legality of any claimed title or right would be 'barred'. 345 Though Stimson's announcement was spurred by the immediate dispute between China and Japan in Manchuria, the League's endorsement meant it now formed a new general principle.

In his 1929 paper, Williams noted that recognition had reached a level of urgency in the 'agitated times' after the Great War-namely because of the raft of new states formed out of the ruins of four collapsed empires - and 'may well involve some fundamentals as to the whole conception of International Law which is to prevail in the modern world'. 346 By 1932, recognition had developed into 'an engine of a hitherto unexpected potency', that might bring into effect the outlawing of war more so than the declaration of that intention. 347 Addressing the 'root problem' of international relations - 'the establishment of some process of peaceful change' to deal with inevitable conflicts 348 -Williams noted that war's usual role in effecting change would require a substitute:

Now, if 'recognition' is to play the part which the new [Stimson] doctrine would assign it, and if (what is essential) it can be regulated by some central authority, we have in it a new method of approaching this problem of change, and we may find that we have taken a big step towards the organisation of a central control over the actions of individual States. ${ }^{349}$

Williams' correspondence contains several expressions of his lack of faith in the Kellogg-Briand Pact: 'I looked at the suggestion of the "outlawry of war" rather sceptically. I doubted, and still doubt at times, whether the idea had been fully thought out'. 350 Nonetheless, he hoped that the Stimson Doctrine, if it proved to be a welldefined and agreed-upon approach to recognition applied by the League entirely, might indeed regulate political changes. In Williams' view, this new wide meaning of recognition was 'a large but not illogical development of the use of the term "recognition". 351 But absent an international tribunal with a respected capacity to pronounce on the 'legality' or otherwise of a situation, treaty or agreement—which

344 See, eg, FP Walters, A History of the League of Nations (OUP 1952); G Scott, The Rise and Fall of the League of Nations (Hutchinson 1973) chs 11 and 12.

345 JF Williams, "The New Doctrine of "Recognition"' (1932) 18 Transactions of the Grotius Society 109, 109, 116.

346 Williams, 'Recognition' (1929), 53.

347 Williams, "The New Doctrine of "Recognition"” (1932), 110.

348 Ibid. See also JF Williams, International Change and International Peace (OUP 1932).

349 Williams, "The New Doctrine of "Recognition"” (1932), 110.

350 JF Williams to Lady Courtney, 18 May 1928 in LSE Archives Ref FISCHER WILLIAMS.

351 Williams, 'The New Doctrine of "Recognition"' (1933), 117. 
ultimately required the 'supremacy of law in the widest sense in international affairs' -we remain 'groping our way' towards peace. ${ }^{352}$ Williams returns again to civilisation, but as an indictment: the Stimson Doctrine could only work if we had indeed 'arrived at the stage of civilisation at which the general sense of civilised mankind can make itself respected, by economic action or otherwise, without resorting to war, or to violence practically indistinguishable from war in its manifestations but not in its legal results'. 353 Williams repeats his 1929 appeal to humanity, which by 1932 would have seemed all the more urgently in danger.

Williams' major work on recognition culminates in his 1933 Hague Academy course, undoubtedly his deepest and broadest inquiry into the history, theory and practice of recognition. Williams begins in a new place, and indeed one of conceptual history: the etymology of the word 'recognition' in its 'proper and original sense' and the act to which it refers. In everyday language, it is the 'act by which a known quality is recognised and admitted for the first time as appertaining to a thing or a person'. 354 In a second sense, recognition attaches to status, such as that of a friend. ${ }^{355}$ In an 'ordinary' legal sense - in domestic and international law alike - it may form part of a ceremony of legal importance: 'the acceptance, by a person having the law to be consulted, of a pretension to a title or quality'.356 Williams' example here is a typically English one: the coronation ceremony of a new English monarch, in which the monarch 'pretends to a title, the English people admit the monarch to that title, and thus recognise the pretension'. ${ }^{357}$ The relevance of these meanings for international law, according to Williams, is to illuminate the nature of this act in international law. Quoting Lorimer's dictum that recognition is the 'foundation of international law', Williams states that 'recent developments assign to it a role of capital importance in international relations'. ${ }^{358}$ His concept of recognition shifts closer to its consequences in strengthening the reach of law across the world:

One must never forget that recognition is an international process by which one submits the actions of a State, independently of its own will, to an external authority. It is a process based on the existence of an international society and the legitimate interest that each State has in some aspects of the conduct of other States. Thus it is a process in which it is normal to search for a means of reinforcing the observation of norms of international law. ${ }^{359}$

Williams' Hague Lectures show a depth of new research. He draws on a range of jurists and world events to chart changes in thinking about recognition, before moving to argue that today's international lawyers ought to give recognition a 'more modest role, a function better suited to its etymological origins' and its history, and contending that the constitutive view's emphasis on recognition's 'affirmation of

352 Ibid, 117-23.

353 Ibid, 129.

354 JF Williams, 'La Doctrine de la Reconnaissance en Droit International et ses Développements Récents' (1933) 44 Recueil des Cours 198, 206.

355 Ibid.

356 Ibid, 206-207.

357 Ibid, 208.

358 Ibid, 209.

359 Ibid. 
objective fact' runs against history and any satisfactory theory of 'human relations' regulated by international law. ${ }^{360}$ Since international law is 'for the moment' focused on the state as its subject, the mere prior existence of earlier states does not confer on them the power to determine which communities do in fact merit the status. ${ }^{361}$ Rather, recognition should be seen as the procedure by which states, 'in their capacity as representatives of the community of the whole of civilised mankind, accept the fact that other men, their equals, have organised themselves into a permanent body endowed with international rights and duties'.362 Williams again strongly disavows the idea that current states enjoy any particular status, particularly to decide on what is civilised.

Williams' post-1933 works condense and recap preceding writings, and begin to acknowledge that recognition could not live up to the promise it held for him. A 1934 article extends some new ideas, ${ }^{363}$ but is mostly notable as a distillation of his final positions. ${ }^{364}$ Williams then does not publish anything further on recognition until a 1939 essay, 'Aspects of International Law', which restates his positions in concise form with additional thoughts on the tension between law and policy. ${ }^{365}$ In this short treatment, Williams' language shifts to failures. Recognition's 'fundamental weakness' as a criterion of existence or legitimacy is that it is an 'uncontrolled individual act of a single state or body of states', and consequently it relates to facts and 'not of the legitimacy of a fact'. ${ }^{366}$ Incoherence results from a lack of legal rules and the absence of a 'central organism of international law'.367 If Williams' longstanding conviction that the hardest problem faced by international law and the international community alike - of how to avoid war while giving effect to changes in international relationships - could be solved, it was increasingly clear that the solution could not, in the end, be found in a theory of recognition.

\section{B. Baty: recognition in service of canon-respecting states}

Thomas Baty (1868-1954) remains one of the most intriguing - if largely forgottenfigures in British international legal history. ${ }^{368}$ Completing his studies at Oxford then

360 Ibid, 236.

361 Ibid, 236-37.

362 Ibid, 237-38.

363 Notably making an interesting analogy that recognising states could be thought of as having fiduciary duties: JF Williams, 'Some Thoughts on the Doctrine of Recognition in International Law' (1934) 47 Harvard LR 776, 780.

364 Ibid, 793-94.

365 Williams, Aspects of Modern International Law.

366 Ibid, 32.

367 Ibid, 33.

368 See esp P Oblas, 'Naturalist Law and Japan's Legitimization of Empire in Manchuria: Thomas Baty and Japan's Ministry of Foreign Affairs' (2004) 15 Diplomacy \& Statecraft 35. There has been a recent resurgence of interest in Baty among international lawyers: see, eg, A Carty, 'Thomas Baty: An International Lawyer as Public Intellectual between Imperial Japan and the Republic of China' (2014) 56 Japanese YB Int'l L 24; V Lowe, 'The Place of Dr Thomas Baty in the International Law Studies of the 20th Century' in S Murase (ed), The Commemorative Seminar for Dr Thomas Baty (2004); S Murase, 'Thomas Baty in Japan: Seeing Through the Twilight' (2003) 73 BYIL 315. 
Cambridge in 1903, Baty wrote extensively on a wide range of topics in international law and taught throughout Britain. Following an unsuccessful bid for the Chichele Professorship at Oxford in 1910, he became legal adviser to the Japanese Foreign Ministry in 1916. He remained in Japan for the rest of his life, save for three short trips to Europe, gradually gaining extensive influence in the Foreign Ministry, and most notably formulating Japan's legal justifications for its actions in Manchuria. Baty's many works rest on a longstanding conviction in a simple naturalism that saw international law as a set of axiomatic 'canons'. 369 Baty understood these canons to contain the true basis of the law of nations, and considered the refusal by international lawyers and statesmen to act in accordance with them-particularly in abrogating them through the consensual agreement that forms the focus of positivism - to lie at the root of all problems of international society. International cooperation, he thought, could amount to little without adherence to these principles. ${ }^{370}$ By the 1930s Baty directly calls for a return to natural law thinking in the mould of Grotius, thus taking a direction far removed from the attempts by Williams and Lauterpacht to reconcile positivist and naturalist thinking. ${ }^{371}$ As Carty notes, Baty's self-understanding of the role of the international lawyer - to seek and clarify the general principles of law within the common consciousness of mankind-focused not on 'institutional utterances, but more to the mentalities of leaders and world society', and was thus aligned with the founding philosophies of the Institut de Droit International. ${ }^{372}$ With an eclectic and polemical writing style, Baty-perhaps better than any other British jurist-represents a distilled last gasp of British nineteenth-century natural law thought. His positions and overall philosophy jar clearly with 'mainstream' views and modes of argumentation in the era, and indeed even in the 1920s he must have seemed a relic of a bygone age. 373 .

Baty is the first British jurist to publish on recognition in the interwar period. A 1921 article, 'So-Called "De Facto" Recognition', contended that the distinction between simple and de facto recognition (that is, of a belligerent) rests on a misapprehension. ${ }^{374}$ Here, Baty introduces a concept of recognition that, consistent with his focus on canonical principles, barely relies on any appeal to what states do or have done, or criteria of statehood. If an area is under an authority that is factually obeyed, and that is not threatened by any other would-be sovereigns, then 'that district is a state, and the authority is its sovereign'. ${ }^{775}$ Supremacy is the only test, and international law is 'superbly careless' of any constitutional, moral or legal right to break from a former sovereign's control. ${ }^{376}$ While the question of supremacy as an issue of fact is not always 'easy' to decide, the decision itself is 'simple': 'a favourable

369 T Baty, The Canons of International Law (Murray 1930). The importance of simple commitments is reflected in the chapter structure of Baty's 1909 textbook, divided into (somewhat esoterically labelled) themes: see T Baty, International Law (Murray 1909).

370 See esp T Baty, 'Danger-Signals in International Law' (1925) 34 Yale Law Journal 457.

371 Baty, Canons; T Baty, International Law in Twilight (Maruzen 1954) 13.

372 Carty, 'Thomas Baty', 27.

373 See Lowe, 'The Place of Dr Thomas Baty'.

374 T Baty, 'So-Called “De Facto” Recognition’ (1921) 31 Yale Law Journal 469.

375 Ibid, 469.

376 Ibid. 
decision is termed recognition'. 377 Recognition does not constitute the state, but it forms the best evidence of its existence, and can be achieved in a range of ways. ${ }^{378}$ Baty disavows any fixed, substantive criteria and criticises the importation of obvious political and ideological preferences into the criteria for recognition:

Nor can one state, or any combination of states, refuse this recognition to a new state or to the new government of an old one simply because it is autocratic or democratic, protectionist or proletarian, heathen or Christian - in other words, because it does not agree with it or does not like it. ${ }^{379}$

Such a refusal, absent a threat to peace and safety, is a serious international offence. Recognition cannot be conditional or bargained but must be unqualified and complete. Moreover, there is no special status for the Great Powers as superior granters of recognition or as arbiters or representatives of a standard of civilisation. All that is required is the fact of cohesion and territorial control. While those facts might be difficult or debateable, there can be no middle ground: 'International law knows of no chrysalis states.' 380 Consequently, the term 'de facto' is a misnomer because 'it is precisely the fact of [the belligerent's] state-hood which is in suspense. What is recognized is simply the fact of their temporary cohesion and momentary independence of control'. 381

This introduces two central themes in Baty's concept of recognition: the impermanence of specific states, and the view that nation-states in general are only a contingent focus for current international law. After examining a range of nineteenthcentury insurrections and diplomatic communications on recognising new revolutionary regimes, Baty suggests that this practice is erroneously grounded on the perceived endurance of particular states:

Much current popular talk proceeds on the footing that a state endures always and for ever, whether it has a settled government or not. Such a position is unknown to all the authorities on the law of nations. If a nation ceases to have a government, it ceases ipso facto to be a state. ${ }^{382}$

The reverse of Baty's clear principle here is that governments remain recognised until 'finally reduced to impotence': to hold otherwise would destroy 'the very basis of confidence and state security' and promote the 'fundamentally anarchic principle' that belligerents might attain some 'indefinite share' of powers in dealing with foreign states. ${ }^{383}$ Baty's views on the impermanence of states, and the potential for change and division, flow from his focus on the relation between territory and authority. A partly successful rebellion can divide a state, and if belligerents can establish an authority that 'makes its will respected in any fraction of the territory, in a reasonably permanent fashion, we have a sovereign state'. 384 While Baty concedes

377 Ibid.

378 Ibid.

379 Ibid, 469-70.

380 Ibid, 470 .

381 Ibid, 471.

382 Ibid, 481.

383 Ibid.

384 Ibid, 484. 
that assessing that will and permanence contains 'enormous' difficulties, the principles on which it is based - 'the simplicity, clearness, certainty, and stability' of the rules of international law-will only be complicated or departed from by charlatan states. ${ }^{385}$

It is in the early- to mid-1930s in the wake of the Manchuria crisisthroughout which Baty had been a principal legal adviser to the Japanese Foreign Ministry - that Baty returns to recognition. In the Canons of International Law (1930), Baty declared that the de jure/de facto distinction has thrown the idea of recognition into chaos and that accepting constitutivism would exacerbate that chaos: international law's 'simple and objective system' requires that a state exist or not, and that opinions of others, whether correct or incorrect, do not alter that fact. ${ }^{386}$ In the mid-1930s, he reiterated the major points articulated in the early 1920s and repeated in Canons, though now in the context of a League under challenge and reeling from the Manchuria and Abyssinia crises:

We shall take recognition to mean, what all will agree that it means, the expressly or implicitly announced opinion entertained by an existing State that a certain community has come to constitute a State also. ... this recognition cannot be conditional, revocable or in the long run avoidable. If a State is a State, it remains a State whatever it does; whether it pays its debts or not, and whether it has an efficient police or not. It cannot be a State on condition of good behavior. If a State is acknowledged to be a State, it is futile afterwards to say that the acknowledgment is withdrawn. It cannot be a State at will. For it would not be an independent State at all. It is inconsistent with the very idea of a State that its existence should be wholly dependent on the option of another. And, sooner or later, the two communities will come into contact, and the old State cannot refuse to treat the new State as such without exactly the same shock to the universal consciousness as occurs when rights are refused to a recognized State. ${ }^{387}$

This reflects Baty's sharp, factual approach. Elsewhere, Baty argued that international legitimacy differed clearly from constitutional legitimacy, as 'simply the legitimate right to rule, conferred by the fact of having ruled'. 388 Reinforcing facts, Baty concluded that recognition is 'based on a severely realist and wholesome principle, namely, that those who have the rule in fact shall have the rights and responsibility of rule'.389 And while neighbouring states might try to subvert governments or re-establish a 'broken empire' as a suspended state, these projects are not legal claims but mere aspirations to what might be achieved in fact. 390

While at this point Manchuria is not explicitly mentioned, it is clear that itand the criticisms of the League that go with it-lie close to the surface of Baty's work. Baty uses the same language as Williams in linking recognition to the 'close corporation' but from a position of exclusion and after Japan's exit. He writes that the 'heretical doctrine' that recognition can be 'contradicted by words' and is a 'pure favor' probably lies in 'the theory that the family of States is a close corporation, into which no new member can be admitted without the arbitrary consent of those which

385 Ibid, 487.

386 Baty, Canons, 203-204.

387 T Baty, 'Abuse of Terms: "Recognition": "War"” (1936) 30 AJIL 377, 377.

388 T Baty, 'Can an Anarchy Be a State?' (1934) 28 AJIL 444, 446, and see at 454.

389 Ibid, 454.

390 Ibid. 
exist'. ${ }^{391}$ Statesmen, Baty writes, are attempting to 'destroy' the principle that the fact of independence and recognition by others makes a 'fully-fledged State for all purposes, whether the States which have been compelled to show that they admit its existence like it or not'. 392

Baty's arguments disclose a clear scepticism about the kinds of political agendas that states might use to criticise or modify the legal principles underlying recognition. Like Lauterpacht below, Baty's concept of recognition seeks to curtail those policy options. But a central problem remained that Japan was alone in its view of the 'facts' of anarchy in Manchuria and a lack of Chinese governmental control in the area. It responded to that opposition by simply leaving the League. In his memoirs, Baty remarks of Manchuria and Japan's exit that it 'had always been obvious to me that a distant, different and inarticulate state like Japan would be at a great disadvantage in the League ... It would have been better to have remained outside'. 393 While for the members that remained Japan's exit was read as a refusal to submit to law, Baty saw it as simply Western inability to accept the facts of a lack of authority or control by China over Manchuria, ${ }^{394}$ and more broadly to properly appreciate what the canons of international law demanded.

While Baty's dedication to Japan is plain from 1916 onwards, ${ }^{395}$ we can perhaps discern early versions of these theoretical positions in works predating his Japanese appointment, particularly his criticism of the centrality of nation-states and his use of the example of China as an unstable nation. ${ }^{396}$ But as an adviser to a relatively new Great Power, and in scholarly works that are occasionally put forward as an explanation of Japan's reactions to European powers, Baty's views on international law and his criticisms of European arguments have a 'new world' bite. ${ }^{397}$ In one sense, Baty represents older European ideas coming back to haunt and challenge the arguments of newer interwar theorists who saw themselves as looking to positivism, formalism and institutions to prevent what they took to be the excesses that caused the War. Somewhat ironically, Baty's concept of recognition and the older natural law arguments that undergird it are deployed by the 'new' state of Japan to frustrate and undermine a project of European international cooperation: Baty and Japan held closely to the language of anarchy, the incapacity to control territory, and ideas referred to by jurists like Westlake to deny statehood and recognition to native tribes.

391 Baty, 'Abuse of Terms', 380. Baty later became more explicit in his defence of Japan's actions, accusing the Great Powers of propping up a 'phantom China' that lacked any territorial integrity: Baty, Twilight, ch 3, esp at 23.

392 Baty, 'Abuse of Terms', 380.

393 T Baty, Alone in Japan: The Reminiscences of an International Jurist Resident in Japan 1916-1954 (Maruzen 1959) 138.

394 Ibid, 139.

395 See generally ibid.

396 See Baty, International Law, 326 (on Chinese federal control), 341-42 (suggesting China as a possible 'typical' 'association-state'), and generally ch 9 (on the 'association-state') which perhaps presents an early critique of the centrality and continuity of nation-states.

397 See, eg, Baty's trenchant criticisms of the terms of administration of protectorates and mandates, which he indicates 'has caused great and legitimate astonishment in Japan': T Baty, 'Protectorates and Mandates' (1921) 2 BYIL 109, 119 (footnotes omitted). 


\section{Lauterpacht: recognition in service of community and international law itself}

As has been widely acknowledged, Hersch Lauterpacht (1897-1960) was one of the most prominent and influential British international law jurists of the twentieth century. ${ }^{398}$ In contrast to Williams and Baty, Lauterpacht was younger by thirty years, a naturalised British subject born in Poland, Jewish, 399 educated not at Oxford or Cambridge but in Vienna under Hans Kelsen and then at the London School of Economics under McNair. Consequently, Lauterpacht combined the continental and British traditions of law and theory - taught in both cases by a pre-eminent figure in those traditions - and worked primarily as an academic. Lauterpacht is commonly regarded as an idealistic, progressive thinker who nonetheless understood the importance of thoroughly understanding the concrete realities of the interwar world. Lauterpacht's early theoretical work is dedicated to demonstrating the moral possibilities of a world functioning through law and principle rather than power or arbitrary decision-making, in which all disputes or questions were justiciable and any and all purportedly 'political' acts could be restrained through law. ${ }^{400}$ Lauterpacht's conception of law is profoundly and fundamentally German, despite his adopted affinity for British methods. 401 Departing slightly from his teacher Kelsen, ${ }^{402}$ Lauterpacht held that the methods of deduction and system-building must pay heed to the facts of the international community if law is to function: state practice ought to be invoked as evidence of consent where it accords with an understanding of the general principles of international law. ${ }^{403}$ But, consistent with the new expansion of judicial decisions on international law, in particular by the new Permanent Court of International Justice, a central question preoccupying Lauterpacht was the nature of justiciability of questions of international law and the purported division between law and policy, which he critiqued carefully in his promotion of law over policy. 404

These aspects of method and ideology are reflected in Lauterpacht's concept of recognition. Lauterpacht's focused thinking on recognition began in 1937 following a prompting from McNair to prepare a new monograph. ${ }^{405}$ The text was completed by 1939, but due to the Second World War it could not be published as a monograph until

398 See, eg, M Koskenniemi, 'The Function of Law in the International Community: Introduction' in H Lauterpacht, The Function of Law in the International Community (OUP 2011 [1933]); E Lauterpacht, The Life of Hersch Lauterpacht (CUP 2010); Koskenniemi, Gentle Civilizer, ch 5.

399 On the influence of Judaism on Lauterpacht's thought and methodology, see RY Paz, 'Making It Whole: Hersch Lauterpacht's Rabbinical Approach to International Law' (2012) 4 Goettingen Journal of International Law 417.

400 See generally H Lauterpacht, Function of Law.

401 See H Lauterpacht, 'The So-Called Anglo-American and Continental Schools of Thought in International Law' (1931) 12 BYIL 31; Koskenniemi, 'Introduction', in H Lauterpacht, Function of Law, xxxv-xxxvi; P Capps, 'Lauterpacht's Method' (2012) 82 BYIL 248.

402 See further H Lauterpacht, 'Kelsen's Pure Science of Law' in WI Jennings (ed), Modern Theories of Law (OUP 1933) 105.

403 See esp Capps, 'Lauterpacht's Method'.

404 See H Lauterpacht, Function of Law, Preface.

405 See E Lauterpacht, Life of Hersch Lauterpacht, 84-85. 
1947 ; in the meantime, parts appeared in journals. ${ }^{406}$ Lauterpacht's extensive writings defend a mixed constitutive/declaratory concept that he contended reflected both the general principles of international law and the actual practice of states:

To recognize a community as a State is to declare that it fulfills the conditions of statehood as required by international law. If these conditions are present, existing States are under the duty to grant recognition. In the absence of an international organ competent to ascertain and authoritatively to declare the presence of requirements of full international personality, States already established fulfill that function in their capacity as organs of international law. In thus acting they administer the law of nations. This rule of law signifies that in granting or withholding recognition States do not claim and are not entitled to serve exclusively the interests of their national policy and convenience regardless of the principles of international law in the matter. Although recognition is thus declaratory of an existing fact, such declaration, made in the impartial fulfillment of a legal duty, is constitutive, as between the recognizing State and the new community, of international rights and duties associated with full statehood. Prior to recognition such rights and obligations exist only to the extent to which they have been expressly conceded or legitimately asserted by reference to compelling rules of humanity and justice, either by the existing members of international society or by the community claiming recognition. ${ }^{407}$

The foundation here is an 'international social reality' that exists and furnishes the facts that states interpret. But that interpretation always occurs through principles of international law. This social reality has been shorn of all civilisational criteria. Lauterpacht insisted that international law generally_and recognition specificallyno longer distinguished between civilised and uncivilised states or held certain states to be outside an international community of civilised states. ${ }^{408}$

In a footnote to a co-authored work on recognition, Lauterpacht addresses prevailing views quite candidly. Lauterpacht's disagreement with the 'majority' of international lawyers is that they treated 'aspects of recognition, connected as they are with fundamental manifestations of the life of States ... largely from the political and diplomatic rather than the legal point of view' and consequently they do not associate facts with legal criteria or duties. 409 Rather, the 'more accurate view' is that 'conditions of fact identical with conditions of statehood as laid down in international law gives rise, respectively, to the right to recognition as a State and to the duty of recognition on the part of existing States'. ${ }^{410}$ Facts are to be read through legal conditions, giving rise to a correlative right and duty of recognition.

Koskenniemi's reading of Lauterpacht is illuminating for understanding the place of his concept of recognition within his broader project. Lauterpacht turns to international cooperative processes to exit the 'circle of interpretative problems' which was the problem of modern law: that facts are required to constrain political will, but

406 See H Lauterpacht, 'Recognition of Insurgents as a De Facto Government' (1939) 3 MLR 1; H Lauterpacht, EM Borchard and P Morrison, 'The Principle of Non-Recognition in International Law' in Q Wright (ed), Legal Problems in the Far Eastern Conflict (Institute of Pacific Relations 1941) 129; H Lauterpacht, 'Recognition of States in International Law'; H Lauterpacht, 'Recognition of Governments: Part I' (1945) 45 Columbia LR 815; H Lauterpacht, 'Recognition of Governments: Part II' (1946) 46 Columbia LR 37.

407 H Lauterpacht, Recognition in International Law (CUP 1947) 6.

408 H Lauterpacht, Recognition, $31 \mathrm{n} 1$.

409 Lauterpacht, Borchard and Morrison, 'Principle of Non-Recognition', 129-30 n 2.

410 Ibid. 
facts must also themselves be interpreted. ${ }^{411}$ Lauterpacht sought to do this by articulating and defending a faith that diplomatic practice in accordance with international law within a democratic international organisation could regularise these diplomatic debates about facts underlying recognition. ${ }^{412}$ As other commentators pointed out at the time, the formalisation of recognition criteria into application requirements for admission to the League had made these debates extremely confusing and often combative. ${ }^{413}$ But as Koskenniemi concludes, 'Lauterpacht's utopia was not unworkable because diplomats were unwilling to imagine themselves as judges but because, to judge wisely, they needed to be good diplomats!'. 414

Lauterpacht's recognition is a final rumination on what might have been achieved in the interwar period if only law, diplomacy and the concrete international social reality could have brought into proper contact. By 1937, the excesses of national policy in Manchuria, Abyssinia and Spain and the apparent inevitability of a new war with Germany confirm that the League and its legal framework had failed. But for Lauterpacht it is a failure of framework, not of law itself, and that failure does not undermine the possibility that states' adherence to law might still deliver peace and stability. For Lauterpacht, the context of failure is seemingly beside the point. Law is the selection and interpretation of facts, and, while the recurring deep conflict in legal theory between law and fact may not be soluble, the way forward is acceptance that recognition involves legal interpretation. States will continue to dispute and disagree; but when they do it will be about questions of law, not of policy or interest. Like Baty and Williams, Lauterpacht's scepticism about formalism's narrow focus on state conduct was based in his conviction that general principles underlie international law as a system. But unlike Baty's refusal to bring his canonical principles into contact with the concrete international situation, or Williams' rather simplistic appeals to civilisation, Lauterpacht's more nuanced appeal to general principles forms a much clearer reinforcement for his concept of recognition. A post-war order might cling better to law and promote the interests of individuals, the self-determination of political communities, international cooperation and lawfulness, rather than only the policy preferences of states. ${ }^{415}$ If Williams showed recognition's urgency and possibilities, and Baty demonstrated why it could not work, Lauterpacht both reminds us why it failed even as he urges us to maintain our faith in the possibilities of international law.

D. Recognition as a basic concept in international law

411 Koskenniemi, Gentle Civilizer, 387.

412 Ibid, 387-88.

413 See, MW Graham, The League of Nations and the Recognition of States (University of California Press, 1933) esp 20-28. My thanks to Megan Donaldson for raising this point.

414 Koskenniemi, Gentle Civilizer, 388.

415 H Lauterpacht, Function of Law. See also Koskenniemi, 'Introduction', in H Lauterpacht, Function of Law; Paz, 'Making it Whole', 423. 
Rather than exploring the heavy critical reception Lauterpacht's theory received, ${ }^{416} \mathrm{I}$ conclude this section by considering how Lauterpacht, Baty, and Williams' works demonstrate recognition's emergence as a basic concept. In these writings, recognition has attained the status of a concept central to the making of international legal arguments. Each author offers a concept of recognition that incorporates a temporal aspect of wider philosophical, historical and teleological narratives about law and its place in international society; albeit with very different narratives. Each author reflects and suggests recognition's relevance in broader discussions beyond jurists alone, in the work of international bureaucrats, domestic politicians and members of the public. In each case, the concept of recognition holds a central place in wider ideological and political projects, including equality, the removal of civilisational criteria, peace, the role of the state, cooperation through international law, and ultimately the nature of international law itself. And the concrete facts used in each theory reflect the use of recognition throughout the interwar period by antagonistic political actors to further their ends. It is, above all, fundamentally contested and contains a range of meanings capable of being pressed to serve many projects.

Each of these jurists conceptualised recognition as an argument about the application of principles of international law. This lies in stark contrast to the diplomatic focus of the first strand of recognition theories and the chauvinist racism of Lorimer, and is far more advanced than the often haphazard mix of diplomatic practice with political, social and legal principles that began to emerge in the discussions of the late colonial era. Williams, Baty and Lauterpacht each reflect some resistance to and critique of the hierarchies of political communities that their predecessor jurists had contributed to constructing. Nonetheless, they each held their own ideologies of what international society ought to look like, and how recognition specifically-and international law generally - could ameliorate the damage that the development of the international legal order had wrought so far. Their concepts of recognition differ so starkly partly because of the differences in their political projects, and those differences are tragically clarified, too, by the ultimate inability of lawyers or politicians to achieve the radical expectations these jurists placed upon international law. But in their attempts, these works reflect recognition's attainment of the status of a basic concept of international law: an account of the nature of states, the requirements and nature of admission to international society, and the modes and legal principles allowing or constraining decisions on recognition, all of which are fundamental to their wider arguments about international society, and projects for its improvement through law.

\section{CONCLUSION: RECOGNITION AS A BASIC CONCEPT BY THE 1950S}

Although new British works on the concept of recognition begin to wane in the decades after Lauterpacht's monograph, ${ }^{417}$ works after 1950 by Chen, Fitzmaurice and Schwarzenberger show the entrenchment of declaratory and constitutive theories

416 See, eg, JL Kunz, 'Critical Remarks on Lauterpacht's "Recognition in International Law"” (1950) 44 AJIL 713.

417 G Fitzmaurice, 'The General Principles of International Law Considered from the Standpoint of the Rule of Law' (1957) 92 Recueil des Cours 1, ch 2; H Waldock, 'General Course on Public International Law' (1962) 106 Recueil des Cours 1, ch 9. 
of recognition, alongside candid acknowledgements of the divisive and political nature of recognition. These writings appear in a world in which the British Empire is fast dissolving, and in which discourses of international law are about to move from recognition to self-determination and decolonisation as the avenues to sovereignty, statehood and membership of the international community. Recognition debates did not cease after 1950. They held - and still hold - clear political significance in contests over disputed territories, intellectual or otherwise. Rather the 1950s succinctly illustrates how those debates settle, somewhat, into the diametric doctrinal oppositions of declarative and constitutive that we know today. The lead-up to decolonisation also shows how political projects in international law begin to shift in different directions, away from recognition.

When Lauterpacht's work appeared, Ti-Chiang Chen was in the 'final stage' of preparing his doctoral thesis at Oxford under the supervision of Brierly. ${ }^{418}$ While Chen had returned to China by the time The International Law of Recognition appeared in 1951, Chen's work can be read as thoroughly 'British' by his training, Brierly's influence and his choice of British and United States case law. Chen argued, contra Lauterpacht, that constitutive arguments logically entail a denial of the obligatory character of international law and, further, are inconsistent with state and judicial practice, illustrated by Britain and the United States. ${ }^{419}$ Opening the book, Chen refers to the fundamental contestation, and political aspects, of the concept of recognition. He writes that recognition 'is but a reflection of the fundamental cleavage' between those who see states as the 'ultimate source' of international law, and those who take states to be subject to a system of law already determining their rights and duties. ${ }^{420}$ Sir Gerald Fitzmaurice's 1957 Hague Academy lectures judiciously weighed the declarative and constitutive views, concluding with support for the declaratory position. ${ }^{421}$ Partly this is because the old club of nations is now seen to cover the earth. Fitzmaurice said that international society now embraces 'virtually all territories and all peoples ... no longer like a club which is joined, but like a clan or family into which persons are born'. ${ }^{422}$ In 'almost any case that can happen to-day' peoples claiming recognition will 'previously or already have been' be members of a community that, 'either in itself or as part of a wider unit', held full international statehood. ${ }^{423}$ Chen and Fitzmaurice here each reflect aspects of the entrenchment of recognition as a basic concept in international legal thought. For Chen, positions on recognition reflect a 'fundamental cleavage' between two opposed camps. In Fitzmaurice's work the views of those camps are neatly and expertly dissected. By the 1950s the international legal world now covers the entirety of the globe. There are no more newcomers that do not merely emerge from already recognised bodies, and no more civilisations to explicitly exclude. The concept of

418 T-C Chen, The International Law of Recognition, with Special Reference to Practice in Great Britain and the United States (Stevens 1951) xiii.

419 Ibid, 13-29 (on recognition and the obligatory character of international law), 79-98 (on state and judicial practice).

420 Chen, International Law of Recognition, 3.

421 Fitzmaurice, 'General Principles of International Law', ch 2.

422 Ibid, 25.

423 Ibid. 
recognition in their works is both fundamentally disputed and central to projects of international legal argument.

This basicness is most vividly illuminated by Georg Schwarzenberger's comments at the Hague Academy in 1955 on recognition's 'controversial aspects'which, like Chen, he also termed 'deep cleavage[s]':

To anybody who looks with some detachment at any of the warring eclectic doctrines, it must look as if such forthright response to apparently strong provocation indicated the existence of issues deeper than differences in method and interpretation of ambivalent material. In order to understand the temperature of such doctrinal clashes, it is necessary to examine the political functions which, voluntarily or involuntarily, any particular doctrine serves or is made to serve. In this context ... the temperature of the doctrinal clashes in this field alone appears to make out a strong prima facie case for the sociological analysis of the Doctrine of international law. ${ }^{424}$

To Schwarzenberger, this combination of divisions within and between concepts of recognition, and the acknowledgement of the clear political functions they served, is grounds enough to make a sociological analysis of these doctrines and their authorsthe non- or extra-legal factors like political projects, social communities and livesseem worth pursuing. ${ }^{425}$ This account of competing views on the concept of recognition, linked to political projects and argued within a clear community of interlocutors accords entirely with its status as a basic concept in international law.

When Chen's work appeared the beginning of the end of the British Empire was already clear, and by the time Fitzmaurice spoke in The Hague, it had undeniably come to pass. The dissolution of the Empire combined with the advent of the Cold War and impending decolonisation, significantly contributed to and changed the state of international law and the problem of recognition that Fitzmaurice describes. Between the partition of India and withdrawal from Palestine in 1947, the independence of Burma, Ceylon and Egypt, and the Suez Crisis of 1956, British policy under MacMillan moved from 1957 onwards to gradual acceptance of the reality that the Empire could no longer be maintained ; economically, militarily or politically. 426 With the post-war centrality of the United Nations, the theoretical quandaries of the nature of recognition were soon partly overlayed by new focus on admission to membership of the United Nations. ${ }^{427}$ By 1956 the 'logjam' of states that had sought admission but were precluded because of Cold War political struggles had cleared, paving the way for the universality of the United Nations and effectively removing the substantive admission criteria written into article 4 of the UN Charter. ${ }^{428}$ And by the 1960s, the language and political projects of international law had shifted towards decolonisation, self-determination, independence, and the accession of colonial territories to sovereign status. In contrast to the interwar period, 'these territories

424 G Schwarzenberger, 'The Fundamental Principles of International Law' (1955) 87 Recueil des Cours 191, 242.

425 For a contemporary exploration, see J Stone, 'Problems Confronting Sociological Enquiries Concerning International Law' (1956) 89 Recueil des cours 61.

426 See, eg, WR Louis, 'The Dissolution of the British Empire' in J Brown and WR Louis (eds), The Oxford History of the British Empire, Volume IV: The Twentieth Century (OUP 1999) 329.

427 See TD Grant, Admission to the United Nations: Charter Article 4 and the Rise of Universal Organization (Martinus Nijhoff 2009).

428 See ibid, chs 3-4. 
staked their requests for foreign acknowledgement not on the basis of having attained de facto statehood, but on the inadmissibility of their second-class rank in the family of nations'. ${ }^{429}$ Many practising British international lawyers, newly integrated within the Foreign and Commonwealth Office, turned their attentions to new projects of international law, and disputes before the new International Court of Justice. ${ }^{430}$ While the demise of the British Empire certainly was not the sole cause of this state of affairs, it aptly encapsulates both the new international social reality that drastically reduced the urgency and significance of disputes about the concept of recognition in the post-war order, and one important set of reasons for that reality coming to pass, particularly in paving the way for the new centrality of the United Nations General Assembly in the move to decolonisation, with its foundational concept of selfdetermination.

429 Fabry, Recognizing States, 147-48, and see ch 5.

430 See, eg, M Craven, The Decolonization of International Law (OUP 2007) pt 2. 